\title{
O bicameralismo no Brasil: argumentos sobre a importância do Senado na análise do processo decisório federal
}

Paulo Magalhães Araújo'

\section{Resumo}

O texto analisa o bicameralismo brasileiro a partir da perspectiva institucionalista, com vistas a explorar, de forma mais complexa do que o usual na produção sobre o tema, o poder do Senado nas decisões do governo federal. Diferentemente das abordagens mais comuns, que não consideram devidamente o caráter interdependente do funcionamento das câmaras do Congresso Nacional, a análise aqui empreendida explora a combinação institucional entre bicameralismo e presidencialismo de coalizão, para ressaltar que o Senado, por suas prerrogativas constitucionais, é uma casa altamente influente nas decisões do governo federal. No entanto, a análise ressalta, também, que a atuação mais ou menos ostensiva da Casa depende de sua posição no processo decisório, tornando necessária, para uma análise adequada, a consideração dos elementos contextuais tais como a estrutura da coalizão e outros aspectos do da situação de decisão.

Palavras-chave: Instituições políticas. Bicameralismo. Senado brasileiro. Comportamento parlamentar.

\section{O bicameralismo no Brasil: argumentos sobre a importância do Senado na análise do processo decisório federal ${ }^{2}$}

$\mathrm{D}$ epois de mais de 20 anos de produção científica sobre instituições políticas e produção legislativa no Brasil redemocratizado,

1 Professor adjunto de Ciência Política da Universidade Federal do Espírito Santo - UFES. E-mail: pmagal@uol.com.br

2 Agradeço aos pareceristas da Revista, pelos comentários e sugestões que permitiram o aprimoramento do texto. $\mathrm{O}$ artigo é parte dos resultados de uma pesquisa que conta com o apoio financeiro do Conselho Nacional de Desenvolvimento Científico e Tecnológico (CNPq) e da Fundação de Amparo à Pesquisa do Estado do Espírito Santo (Fapes). 


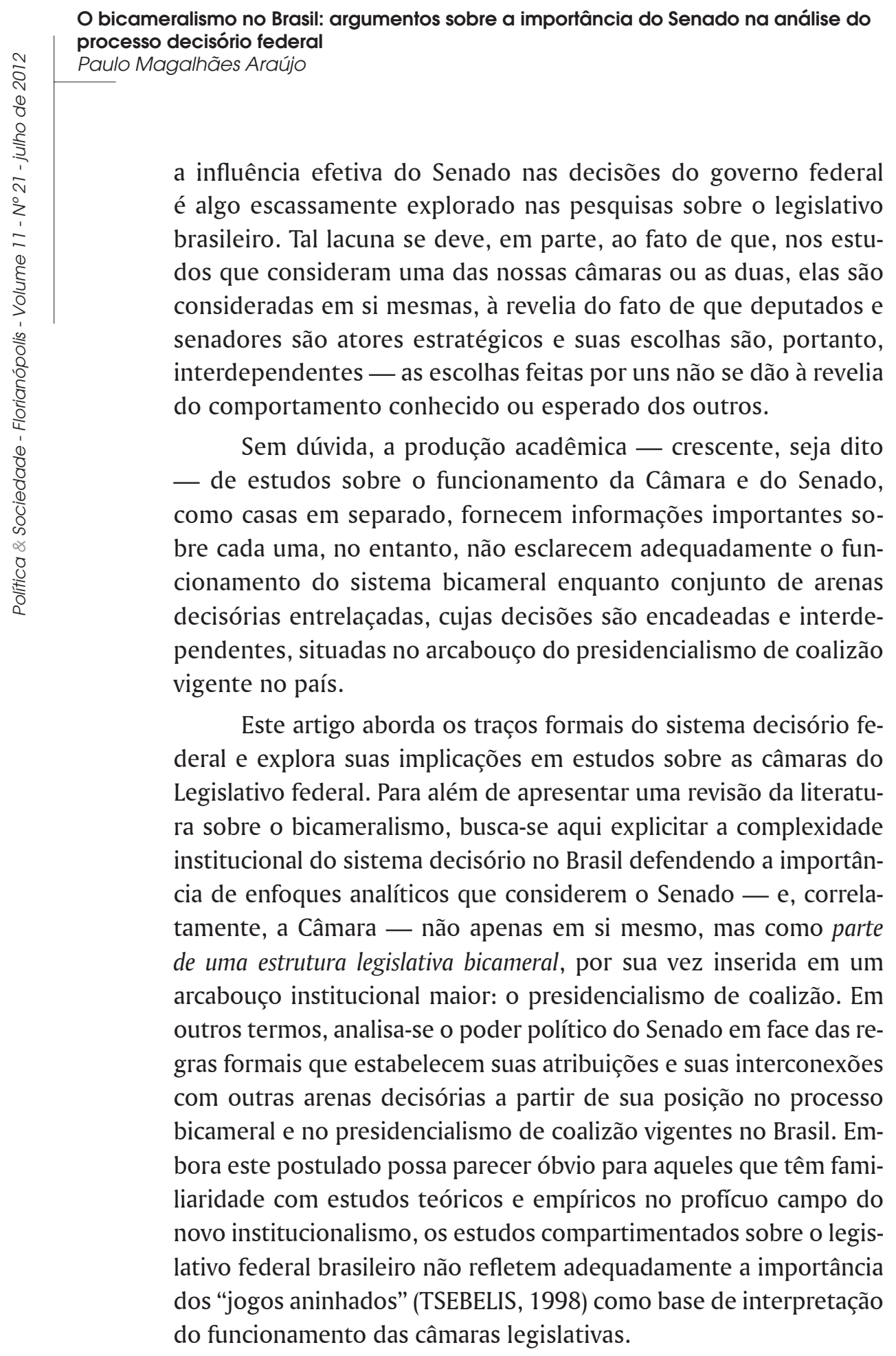


Orientada por essas questões, a análise está dividida em três tópicos. O primeiro tópico apresenta dois referenciais analíticos mobilizados na literatura recente sobre sistemas bicamerais: um é proposto por Tsebelis e Money (1997), que tratam o sistema em termos de sua função política e de sua função de eficiência; o outro é proposto por Lijphart (1989; 2003), que avalia a força do bicameralismo a partir das dimensões da simetria e da congruência. O segundo tópico apresenta os traços institucionais do bicameralismo brasileiro, com o objetivo de analisar o status político do Senado frente ao da Câmara dos Deputados na estrutura do Poder Legislativo. A análise considera as dimensões da simetria e da congruência do sistema, mostrando como ambas reforçam a função política do Senado, permitindo sustentar ideias já difundidas sobre a força do bicameralismo no Brasil.

No terceiro tópico, o Senado é considerado não apenas como parte de uma estrutura bicameral, mas como arena aninhada numa estrutura maior: Estado federativo com governo presidencialista. Essa parte discute a importância das coalizões no funcionamento do governo federal e argumenta que, no contexto de um bicameralismo simétrico e incongruente, é indispensável considerar as características das coalizões, e dos blocos partidários em geral, também na segunda Câmara, que tem um grande poder propositivo e um poder de veto ainda mais notável. Ainda neste tópico são citadas algumas pesquisas recentes que inauguram uma análise do legislativo federal brasileiro como uma estrutura integrada, perpassada por variáveis que condicionam e interconectam o desempenho das câmaras alta e baixa. As considerações finais sintetizam as conclusões alcançadas.

\section{Bicameralismo: breve exposição dos fundamentos analíticos}

O legislativo bicameral é aquele em que as leis são produzidas mediante a deliberação de duas câmaras distintas e autônomas 


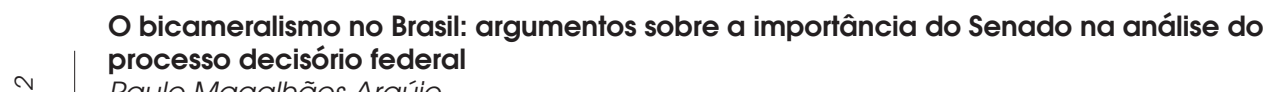

Paulo Magalhães Araújo

entre si (PATTERSON; MUGHAN, 1999). Sua versão moderna surgiu na Inglaterra, no século XIV, e foi reconfigurada para se adaptar ao federalismo dos Estados Unidos, no século XVIII (TSEBELIS; MONEY, 1997; PATTERSON; MUGHAN, 1999).

Nos estudos sobre o bicameralismo, a criação da segunda câmara — também chamada câmara alta ou, muitas vezes, senado — tem sido justificada e analisada à luz de suas funções no processo de produção de leis. Nesse campo, diversos teóricos têm destacado a importância do senado como obstáculo contra decisões tirânicas a que estão propensas as câmaras únicas, compostas em bases populares (MONTESQUIEU, 1973; HAMILTON et al., 1979; MILL, 1981). Para além de sua função de contrapeso ao poder da maioria, argumenta-se que a segunda câmara favorece a qualidade da legislação, incrementa a representação de interesses e aumenta a estabilidade das decisões políticas, protegendo-as dos arroubos dos legisladores (HAMILTON et al., 1979; TSEBELIS; MONEY, 1997; PATTERSON; MUGHAN, 1999; LIJPHART, 1989; 2003).

Nessa perspectiva funcional, um modo parcimonioso de analisar o bicameralismo é apresentado por Money e Tsebelis (1992), Tsebelis e Rash (1995), Tsebelis e Money (1997). Os autores observam que as várias funções historicamente associadas ao sistema bicameral podem ser reduzidas a apenas duas: a função de eficiência e a função política.

A função de eficiência é produto dos esforços convergentes das duas câmaras para formular as políticas mais adequadas à solução dos problemas em foco. Em comparação com a representação unicameral, a representação bicameral amplia o leque de experiências e de pontos de vista do conjunto dos legisladores, possibilita a apreciação reiterada das matérias em decorrência das idas e voltas $^{3}$ dos projetos entre as casas, bem como estendem o tempo

3 Navette system na literatura francesa sobre o bicameralismo; shuttle system, na literatura inglesa. Em ambos os casos, o termo se refere a um sistema de postagem ou de transporte que interliga dois pontos com idas e voltas regulares. 
de deliberação para o amadurecimento das ideias parlamentares. Com isso, o bicameralismo cria condições mais favoráveis para deliberações bem informadas e menos sujeitas a equívocos.

Segundo os autores supracitados, o esforço pela eficiência não gera conflito nas relações intercamerais, pois, enquanto "eficiente", a dinâmica deliberativa consiste num jogo de soma positiva, em que os trabalhos das duas câmaras se complementam na busca de uma solução pareto-ótima para as questões enfrentadas. Isso significa que o processo de deliberação eficiente procura a melhor formulação possível para as políticas, de modo que as alterações eventualmente feitas nos projetos visam atender melhor a pelo menos um interesse, sem que nenhum outro seja prejudicado. Em síntese, pela função de eficiência, a tramitação bicameral tende a produzir decisões com a melhor qualidade possível, dentro das possibilidades dadas pelos interesses políticos em cena.

$\mathrm{O}$ aspecto propriamente conflitivo da relação entre as casas se expressa na função política ou redistributiva do processo legislativo bicameral. Enquanto arenas distintas e autônomas de representação, as câmaras tendem a defender interesses diversos e muitas vezes contraditórios entre si. Quando isso se dá, as relações intercamerais assumem características de um jogo de soma zero, pois as decisões políticas de uma câmara implicam perdas aos interesses defendidos na outra (TSEBELIS; MONEY, 1997). Nessas situações de conflito, o potencial de veto do sistema se manifesta, de modo que a tomada de decisões passa a depender de concessões e acordos que os agentes parlamentares são capazes estabelecer.

Combinadas, a função de eficiência e a função política englobam as diversas funções do bicameralismo enumeradas na literatura. A atuação eficiente redunda em reflexão, ganhos de informação e deliberação qualificada, evitando decisões passionais, apressadas ou mal planejadas. A dimensão política ou redistributiva induz à formação de consensos entre uma pluralidade de interesses, favorecendo a representação democrática, o controle mútuo entre 
as casas e, em última instância, o combate aos abusos políticos, à corrupção e à tirania ${ }^{4}$.

Tsebelis e Money afirmam que a mera existência de uma segunda câmara — quaisquer que sejam suas prerrogativas - é suficiente para que o desempenho da primeira se modifique, visando formular projetos tecnicamente melhores e mais representativos. Segundo os autores, isso ocorre porque os parlamentares da câmara de origem buscam captar, por antecipação, as preferências e opiniões dos revisores, de modo a reduzir as possibilidades de veto, obstrução ou mesmo polêmica na etapa de revisão (TSEBELIS; MONEY, 1997).

Essa assertiva é consistente com a racionalidade estratégica dos representantes, mas obviamente não minimiza a importância da distribuição de poderes entre as casas. É certo que o impacto da segunda câmara na atuação da primeira aumenta de acordo com o potencial dos revisores para intervir na formulação dos projetos nas idas e voltas da tramitação bicameral. Na literatura, esse potencial tem sido mensurado a partir de duas dimensões do sistema: a da simetria e a da congruência.

A simetria é um conceito que remete a um continuum "simétrico-assimétrico", onde os sistemas bicamerais podem ser dispostos

4 O processo deliberativo bicameral é suscetível também de críticas, e recebeu muitas. Se, por um lado, há argumentos, como os de Montesquieu (1973) e de 0 Federalista (1973), que defendem a separação do legislativo em câmaras distintas e equivalentes em poder, por outro, há os defensores de posição contrária, como Carl Schmitt (1981), que veem no bicameralismo uma divisão desnecessária e inconveniente do Poder Legislativo. Para estes autores e críticos afins, os efeitos mais sensíveis de uma segunda câmara no processo decisório seriam a incoerência, a lentidão e os entraves à mudança — em desrespeito à vontade do povo, entendida como una, homogênea e passível de ser representada em uma única câmara. Uma fala do Abade Sieyès, citada em epígrafe de Tsebelis e Money (1997:1), sintetiza bem os argumentos contrários à existência de uma segunda câmara legislativa: "se a segunda câmara concorda com a primeira, ela é inútil; se discorda, ela é ruim”. As manifestações teóricas contrárias ao bicameralismo são importantes para enriquecer os debates sobre sistemas de governo, esclarecer a opção pelo unicameralismo e aprimorar a estrutura institucional do Legislativo, em particular, e do sistema de governo, como um todo. Entretanto, neste trabalho essas críticas não serão desenvolvidas. Como argumenta Llanos (2002), uma vez que o objetivo é estudar o parlamento de um país que, como o Brasil, optou pelo sistema bicameral, supõe-se que, na fase de formação institucional, os argumentos em favor da segunda câmara foram mais convincentes do que os contrários a ela. 
conforme o poder de uma casa para fazer frente às decisões da outra (LIJPHART, 1989; 2003). Tal poder resulta da distribuição formal das prerrogativas e funções de cada casa no processo bicameral, de modo que os graus de simetria de determinado sistema estão estreitamente vinculados à modelagem constitucional do Legislativo. Quanto mais equilibrada a distribuição formal do poder político entre as duas câmaras, maior a simetria e, portanto, maior a força do bicameralismo.

Sem dúvida, a lista de direitos relativos aos campos de atuação política de cada casa é um importante fundamento da simetria - como exemplo, pode-se mencionar que o bicameralismo é mais simétrico na Argentina e nos Estados Unidos, onde todo e qualquer projeto de lei precisa ser aprovado no senado, do que na Alemanha, onde os senadores só atuam em questões que afetam o pacto federativo (PATTERSON; MUGHAN, 1999). No entanto, para além da amplitude do campo de atuação das casas, Tsebelis e Money (1997) destacam outro fundamento constitucional do equilíbrio bicameral: as regras para a interação das casas entre si, especialmente em situações de impasse.

A forma mais comum de interação bicameral é o mencionado sistema de idas e voltas, que determina condições para a remessa das matérias de uma casa para outra. Por norma geral, após aprovar determinado projeto, com ou sem alterações, a casa de origem o envia para a câmara revisora. Havendo concordância dos revisores, o projeto é remetido ao Executivo para sanção. Mas quando não há consenso entre as casas, vários instrumentos são utilizados, conforme o país, para dar sequência à tramitação.

A forma mais comum de solução de impasses é o retorno do projeto à casa de origem e, eventualmente, o prosseguimento das idas e voltas para possibilitar um consenso bicameral ${ }^{5}$ (TSEBELIS;

5 Isso é o que ocorre no Brasil na tramitação de Proposta de Emenda Constitucional (PEC). Depois de aprovada em uma Casa, digamos, a Câmara, a PEC segue para o Senado, onde é apreciada. Se o Senado aprovar o texto como o recebeu da Câmara, a emenda é promulgada pelas Casas. Mas se o texto for alterado, a PEC volta para a Câmara, para ser votado novamente. "A proposta vai de uma Casa para outra (o chamado pingue-pongue) até que o mesmo texto seja aprovado pelas duas Casas". Disponível em: < http://www2.camara. gov.br/agencia/noticias/70153.html> . Acesso em: 3 dez. 2011. 


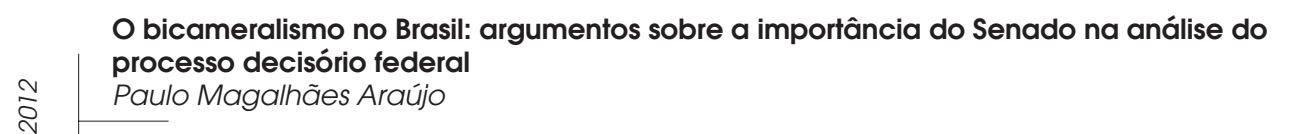

MONEY, 1997). Contudo, em geral, na tramitação bicameral as rodadas são limitadas por alguma regra terminativa (stoping rule), que interrompe as negociações e força a decisão final (idem). Respeitado o número de rodadas previstas, que varia de país a país, algumas constituições atribuem à casa iniciadora o poder de por fim aos impasses, enquanto outras instituem métodos que mitigam os efeitos do bicameralismo, determinando que os dissensos sejam resolvidos em comissões mistas ou sessões conjuntas do congresso. O primeiro caso pode ser exemplificado pelos Estados Unidos (SINCLAIR, 1999, p. 50-52), o segundo pelo Brasil e pela Venezuela pré-Chaves (ARAÚJO, 2005; 2009).

As possibilidades de combinação de regras desse tipo são muitas, e cada arranjo tem efeitos distintos sobre o desempenho do bicameralismo. Some-se a isso o fato de que a maior parte dos sistemas bicamerais têm regras diferenciadas para a apreciação de legislação financeira e não financeira (TSEBELIS; MONEY, 1997). A despeito dessa variabilidade, algumas generalizações podem ser feitas acerca dos efeitos das regras de interação sobre a força do bicameralismo: (a) a casa que tem maior controle sobre o tempo de tramitação leva vantagem sobre a outra, tal que os graus de simetria variarão conforme a distribuição desse poder entre as casas em situações específicas interação; (b) se o número de idas e voltas for indefinido e se o poder de veto das câmaras for mútuo, o sistema é simétrico; (c) se a casa iniciadora tem a palavra final, o bicameralismo é simétrico, desde que a tramitação dos projetos possa ter início em qualquer das câmaras, independentemente da autoria das matérias; (d) se os impasses são resolvidos em comissão mista, o sistema é simétrico, desde que a decisão da comissão seja conclusiva e que o método de votação mantenha o poder de veto de uma casa sobre a outra; (e) se os impasses são resolvidos em sessão conjunta das câmaras, o sistema é simétrico se as votações forem separadas ou se os votos forem ponderados de acordo com número de membros de cada casa.

Ainda sobre a simetria, é importante enfatizar que seu impacto no desempenho do bicameralismo não depende de que as 
câmaras revisoras efetivamente atuem como instâncias de veto. A simples possibilidade de obstrução por parte dos revisores induz os demais atores da cadeia decisória a antecipar suas preferências (TSEBELIS; MONEY, 1997). Com isso, grande parte da influência política da segunda câmara não se deve a sua intervenção direta no processo decisório, mas decorre da possibilidade de obstrução por parte dos revisores, relativamente a decisões tomadas na primeira câmara ou em outras instâncias do sistema.

Passa-se agora à incongruência, outro fundamento da força do bicameralismo. Assim como a simetria, ela remete a um continuum, cujos polos "congruente" e "incongruente", permitem situar e comparar os bicameralismos em termos de seu potencial político. O conceito de incongruência se funda no pressuposto de que a disposição de uma casa para contribuir de forma diferenciada nas decisões legislativas - isto é, para efetivar a simetria do sistema - depende da configuração bicameral da representação política. Por sua vez, tal configuração política depende das regras que determinam o perfil dos candidatos e a forma de competição pelas cadeiras de cada casa. Quanto mais essas regras de acesso divergirem entre uma casa e outra, mais incongruente é o sistema e, por decorrência, mais incentivos existirão para a contribuição particular de cada casa na conformação das decisões políticas.

A importância da incongruência para justificar a adoção do bicameralismo é confirmada pelo fato de que nos sistemas bicamerais sempre há exigências e regras diferenciadas para o acesso às vagas parlamentares de uma e outra casa. Tsebelis e Money estudaram 53 países e observaram que 85\% deles têm bicameralismos incongruentes. Ademais, os autores notaram que, mesmo entre os casos considerados predominantemente congruentes, não há sistema onde as duas casas se constituem por meio de regras idênticas (TSEBELIS; MONEY, 1997, p. 53).

Fica claro que a instituição de uma segunda câmara visa promover a eficiência e a representatividade do processo decisório com base em algum grau de divergência na representação bicameral. Assim, no limite, a questão não é se um sistema é ou 


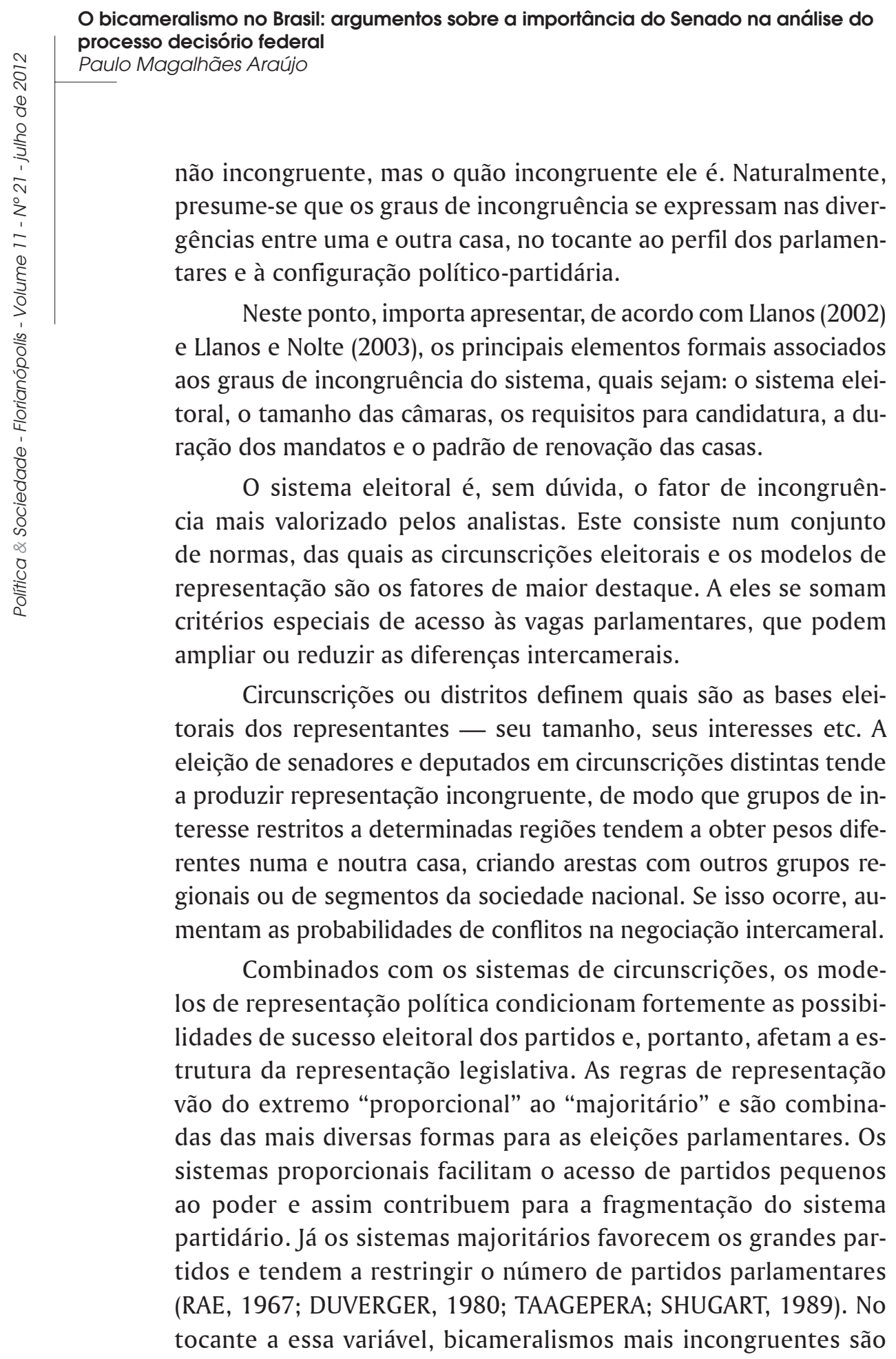


os que adotam regras total ou parcialmente distintas, para fazer variar o peso dos grupos políticos conforme a câmara. Como já dito, alguma incongruência dessa natureza ocorre em quase todos os países bicamerais para promover contrapesos políticos e ampliar os consensos relativos às decisões parlamentares.

Em vários países, além das regras elementares, que definem os distritos e o sistema eleitoral, há regras complementares que estipulam circunscrições secundárias e processos específicos de seleção de parte dos legisladores, principalmente os da câmara alta. Os beneficiários mais comuns das regras especiais são minorias étnicas ou regionais e autoridades ligadas à estrutura do Estado, tais como militares, juízes, ex-presidentes e vice-presidentes. Embora as escolhas costumem ser democráticas no primeiro caso e sejam arbitrárias no segundo, em ambas o objetivo é dar poder a segmentos sociais ou às instâncias institucionais para incrementar os controles - nem sempre democráticos - sobre o processo decisório bicameral.

O perfil e o padrão de seleção dos representantes são fatores de incongruência que afetam a simetria. Em regimes democráticos, governantes eleitos diretamente pelo povo têm mais autoridade frente aos cidadãos que os governantes escolhidos por outros meios. Na medida em que o senado é ocupado por parlamentares nobres ou indicados, com mandatos vitalícios ou temporários, sua legitimidade decai e seu poder é comprometido. Como lembra Stuart Mill, se o sistema é verdadeiramente democrático e tem duas câmaras - uma que representa o povo, outra que representa apenas um segmento social ou é absolutamente não representativa — - a segunda câmara não terá poder efetivo para resistir nem mesmo às aberrações cometidas pela primeira (STUART MILL, 1981, p. 131).

O tamanho das câmaras é outro fator de incongruência (LIJPHART, 1989, 2003; TSEBELIS; MONEY, 1997; NEIVA, 2006). Quase todas as câmaras altas são menores que as câmaras baixas, sendo que, em geral, a diferença é bastante grande. Dados apresentados no sítio da Interparliamentary Union indicam que, em média, 


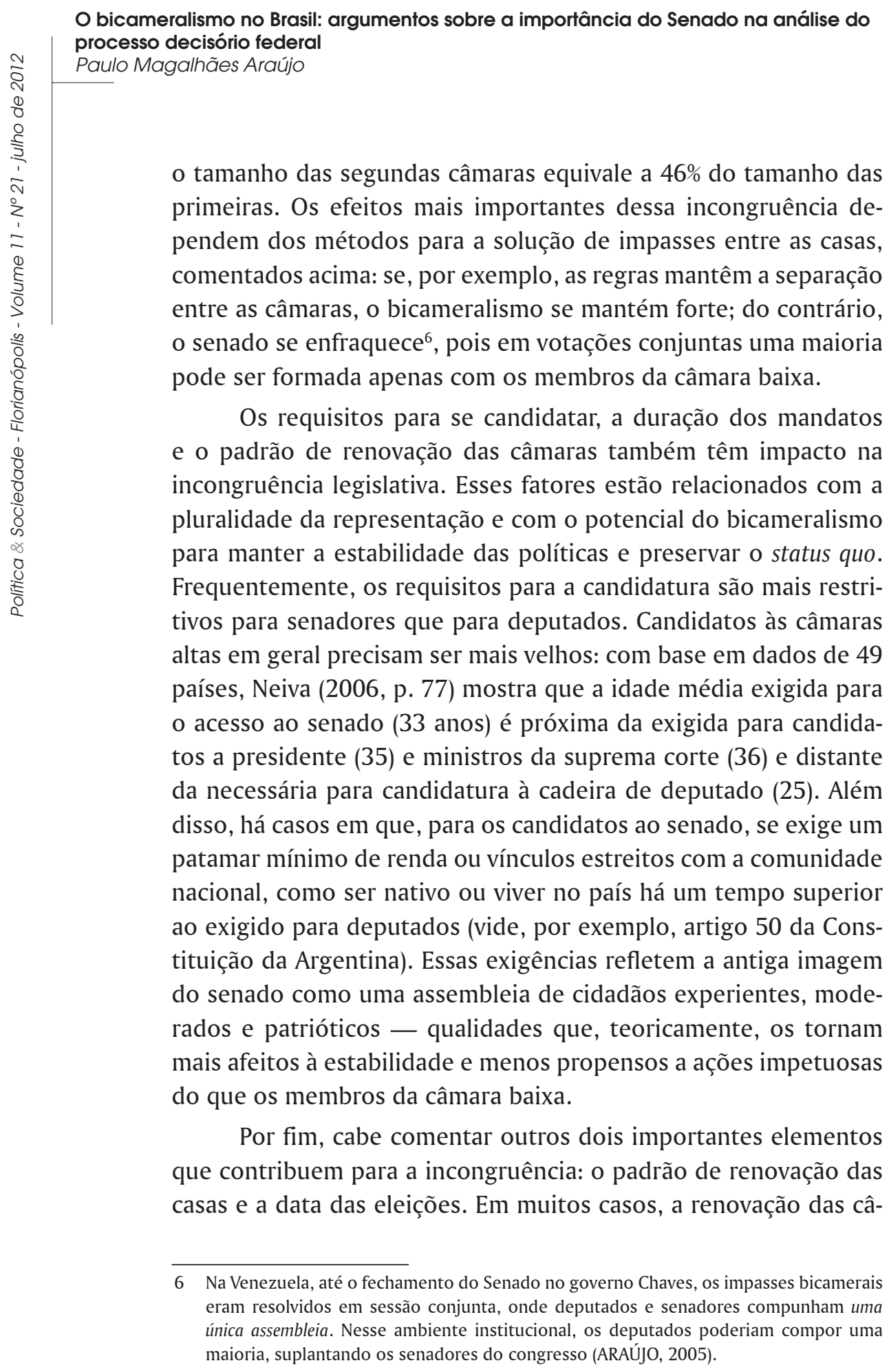


maras altas é escalonada e/ou suas eleições não coincidem com as eleições para as câmaras baixas. Se as eleições são simultâneas para ambas as câmaras, com todas as vagas sujeitas à renovação, se formarão assembleias expressivas de uma mesma "onda" de preferências. Mas como as preferências políticas da sociedade não são fixas, a não coincidência nas datas das eleições, combinada com a renovação parcial dos ocupantes das cadeiras em uma ou ambas as câmaras, constitui elementos adicionais de incongruência. Padrões de renovação distintos, com datas de eleições não coincidentes, se, por um lado, criam um lastro com o status quo, por outro, permitem a atualização das demandas sociais através do voto e, com isso, fomentam a pluralidade legislativa e viabilizam o caráter consensual do processo decisório.

A partir dos parâmetros analíticos acima apresentados, o tópico seguinte aborda o bicameralismo no Brasil. Tendo em vista as determinações da Constituição e da legislação conexa, a análise buscará analisar as características do sistema bicameral brasileiro, para captar os fundamentos institucionais do poder político do Senado Federal.

\section{Bicameralismo no Brasil: a incongruência, a simetria e a força política do Senado}

Inspirado na Câmara dos Lordes da Inglaterra, o Senado foi instituído no Brasil com a Constituição do Império, em 1824. Com a proclamação da República, em 1889, a tradição inglesa deu lugar à influência dos federalistas norte-americanos, de modo que a Constituição brasileira de 1891 não apenas manteve uma segunda câmara legislativa como aumentou sua força para exercer a representação política e o controle constitucional dos demais poderes. Dessa forma, no Brasil, o modelo imperial e a proposta republicana convergiram no tocante à escolha do bicameralismo, permitindo ao Senado tornar-se parte da tradição política nacional. 


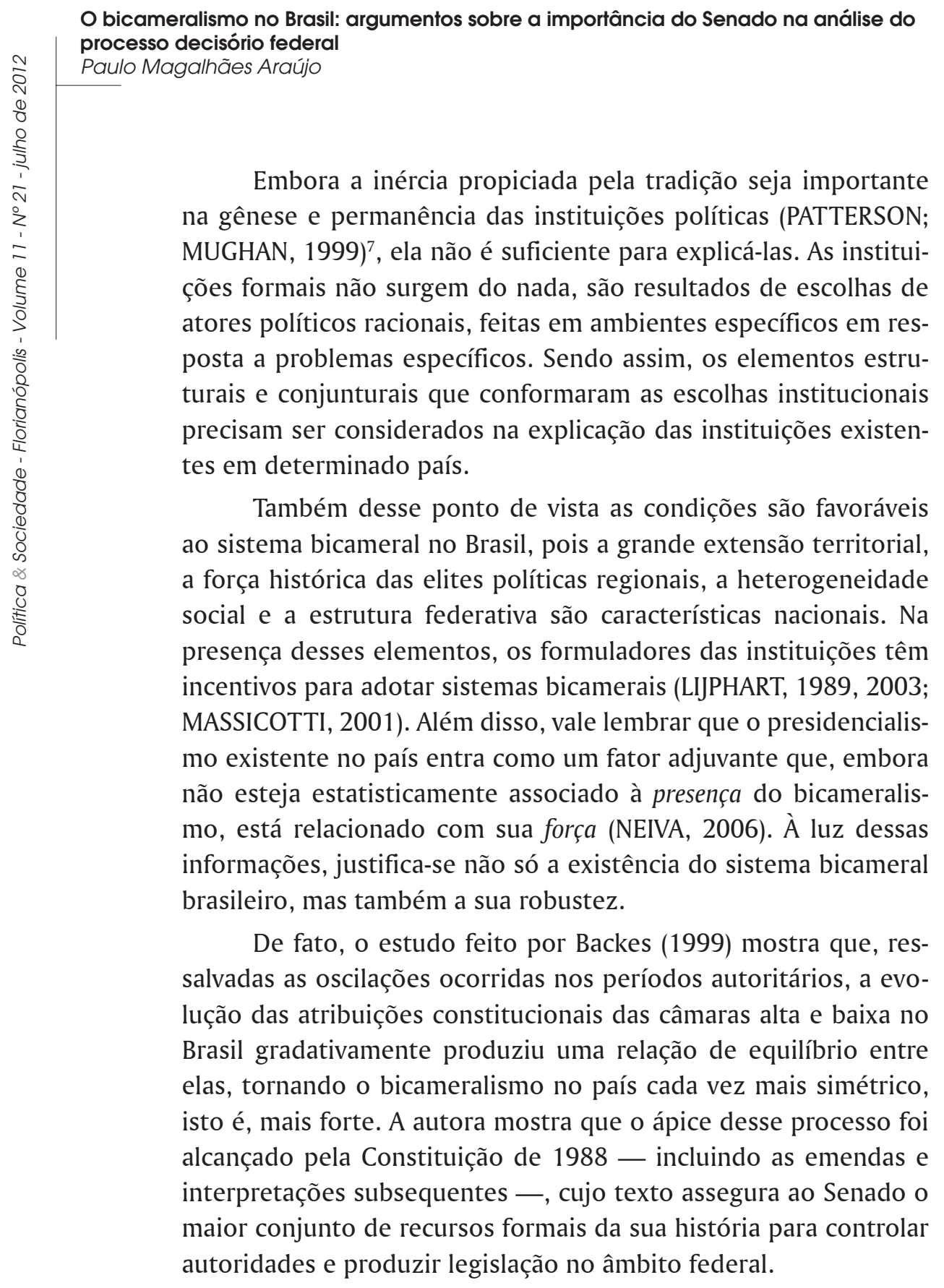

7 It is a tribute to the hidden power of tradition and inertia in the governing affairs of human beings that fundamentals of institution design are rarely laid open to full appraisal. Institutions tend to be accepted at face value. Whether the legislature has one house or two is taken for granted by practitioners, observers and citizens (PATERSON; MUGHAN, 1999, p. 9). 


\subsection{Bicameralismo e incongruência no Brasil}

O modelo de representação parlamentar é um dos principais fundamentos da força do federalismo existente no Brasil. A Câmara dos Deputados abriga os interesses de clivagens sociais que perpassam a sociedade nacional e se constitui por eleições proporcionais, com lista aberta; o Senado, por sua vez, acolhe interesses dos estados federados, signatários do pacto federativo, e se constitui por eleições majoritárias, com candidatos por partido, equivalentes ao número de vagas em disputa. Ademais, em convergência com as funções tradicionais das câmaras altas, as regras para a composição do Senado brasileiro viabilizam a qualificação diferenciada dos senadores, frente aos deputados, e os incentivam a atuarem como contrapesos aos interesses da maioria nacional representada na Câmara. O Quadro 1 sintetiza as características do bicameralismo brasileiro e permite apreender o aspecto geral da representação bicameral conforme as instituições vigentes.

Entre os 11 tópicos listados referentes à constituição da representação bicameral, três são idênticos para ambas as casas: os distritos eleitorais, as datas das eleições e as exigências do artigo 14 da Constituição de 1988 - tocantes à nacionalidade, escolaridade etc. Porém, em contraponto com o que se dá para a Câmara dos deputados, as disputas para o Senado são majoritárias, a renovação é parcial, a magnitude do distrito é baixa e os partidos podem lançar apenas um ou dois candidatos, conforme a eleição, em cada estado. Essa combinação induz não apenas à representação diferenciada dos partidos numa e noutra Casa, mas também promove diferentes vínculos entre os parlamentares e seus apoiadores, sejam eles partidos ou eleitores. Em todo caso se produz uma forte incongruência na representação bicameral. 
O bicameralismo no Brasil: argumentos sobre a importância do Senado na análise do processo decisório federal

Paulo Magalhães Araújo

Quadro 1 - Variáveis que afetam a incongruência legislativa no Brasil

\begin{tabular}{|l|l|l|l|}
\hline \multirow{2}{*}{ Variáveis } & \multicolumn{2}{|l|}{ Regras para composição das casas } & \multirow{2}{*}{ Efeito } \\
\cline { 2 - 3 } & Senado & Câmara & \\
\hline Tamanho das câmaras & 81 cadeiras & 513 cadeiras & Incongruência \\
\hline Sistema eleitoral & Majoritário & Proporcional & Incongruência \\
\hline Tipo de lista & $\begin{array}{l}\text { Um ou dois } \\
\text { candidatos }\end{array}$ & Lista aberta & Incongruência \\
\hline Circunscrição eleitoral & Estado federado & Estado federado & Congruência \\
\hline Magnitude média & $3^{*}$ & 19 & Incongruência \\
\hline Renovação eleitoral & Parcial & Total & Incongruência \\
\hline Data das eleições & Coincidentes & Coincidentes & Congruência \\
\hline Duração do mandato & 8 anos & 4 anos & Incongruência \\
\hline Idade mínima exigida & 35 anos & 21 anos & Incongruência \\
\hline Regras para suplência & Nomeação **** $^{\text {Negra }}$ & Lista de espera & Incongruência \\
\hline $\begin{array}{l}\text { Outros requisitos para } \\
\text { ser candidato }\end{array}$ & $\begin{array}{l}\text { Mesmas } \\
\text { regras***** }\end{array}$ & Mesmas regras & Congruência \\
\hline
\end{tabular}

Fonte: Elaboração Própria, 2008

* Considerando a disputa eleitoral, a magnitude é 1 ou 2, conforme a renovação seja de $1 / 3$ e $2 / 3$ da Casa. O número de candidatos por partido ou coligação é igual ao número de vagas em disputa na eleição em questão.

*** No Senado a nomeação é feita pelo candidato a Senador. Se ele ganha as eleições, seus suplentes também vencem, muito embora estes dificilmente se exponham nas campanhas eleitorais. Na Câmara, os suplentes saem de uma "lista de espera" dos deputados mais votados, mas que não conseguiram votos suficientes para serem eleitos na distribuição de cadeiras que é feita imediatamente após as eleições.

****** 0 § $3^{0}$ do art. 14 da Constituição Federal diz que: "São condições de elegibilidade [para qualquer cargo], na forma da lei: I - a nacionalidade brasileira; II - o pleno exercício dos direitos políticos; III - o alistamento eleitoral; IV - o domicílio eleitoral na circunscrição; V - a filiação partidária; [...] § 40: São inelegíveis os inalistáveis e os analfabetos."

A lista aberta adotada nas eleições para a Câmara é a regra mais criticada do sistema eleitoral no país, porque, em tese, incentiva os vínculos pessoais entre o deputado e sua clientela e induz ao comportamento parlamentar individualista, clientelista e prejudicial à necessária função de coordenação política dos partidos (AMES, 2000; MAINWARING, 1997; 2001). Ademais, não obstante o monopólio partidário da representação, a grande magnitude dos distritos 
e a norma que define o número de candidatos a deputado por legenda permitem que as listas partidárias sejam longas e inclusivas. Considerando-se a pluralidade partidária - fomentada pelas eleições proporcionais -, os candidatos não têm muita dificuldade em conseguir acesso a alguma lista eleitoral, de modo que o monopólio partidário da representação, por si, não se reverte em grande poder dos partidos sobre seus membros. Esses traços institucionais, combinados, incentivariam na Câmara dos Deputados o comportamento voltado para o distrito, ao invés do comportamento partidariamente orientado 8 (SHUGART; CAREY, 1992; MAINWARING, 1997; 2001).

A eleição para o Senado, por sua vez, é majoritária e, conforme dito, a legislação eleitoral restringe o número de candidatos a um ou dois por partido ou coligação, de acordo com o número de vagas em disputa. Nesse caso, os candidatos precisam muito do apoio partidário para ter o nome escolhido na disputa à cadeira em nome da legenda. Ademais, a solidariedade do partido na campanha é importante porque, tanto em termos logísticos quanto financeiros, a disputa para o Senado é mais custosa do que para a Câmara, devido a sua amplitude territorial e ao grande número de votos necessários para a eleição de um senador. Embora o distrito eleitoral seja formalmente o mesmo para deputados e senadores, parece claro que, na prática, a focalização de esforços de campanha e de atenção político-eleitoral em poucos municípios não parece ser estratégia tão viável para os senadores quanto é para os deputados. Este argumento é reforçado por Lemos, Marcelino e Pederiva (2010), cujo estudo refutou a hipótese de que as eleições para a Câmara seriam mais caras por serem mais competitivas, uma vez

8 Essa afirmação é um dos pivôs da atual polêmica em torno do comportamento parlamentar no Congresso Nacional. Estudos como os de Figueiredo e Limongi $(1999,2008)$, Santos (2001), Ignácio (2006), Miranda (2008) rejeitam o argumento do individualismo parlamentar no Congresso Nacional, argumentando que a dinâmica parlamentar, por elementos que lhes são próprios, suplanta os incentivos particularistas oriundos das eleições proporcionais e induzem a comportamentos de base partidária ou coalizacional. Essa questão será melhor abordada adiante. Para uma síntese da discussão, ver Felisbino (2008) e Power (2010). 


\section{O bicameralismo no Brasil: argumentos sobre a importância do Senado na análise do processo decisório federal \\ Paulo Magalhães Araújo}

que são proporcionais e se dão em distritos de maior magnitude. Segundo os autores, os custos da campanha variam também de acordo com o estado onde o candidato concorre e conforme o tipo de candidatura - se pela reeleição (incumbent) ou pelo primeiro acesso a casa (challenger) —, no entanto, as variações observadas não revertem a tendência geral de maiores gastos nas eleições senatoriais (LEMOS; MARCELINO; PEDERIVA, 2010). Enfim, a julgar pelas regras eleitorais, os senadores têm menos incentivos que seus pares da Câmara para estratégias atomizadas e clientelistas e muitos incentivos ao comportamento partidariamente orientado (DESPOSATO, 2003) ${ }^{9}$.

Ainda em relação às regras de constituição da representação, cabe destacar as distintas formas de atualização das legislaturas: restrita para senadores e ampla para deputados. A possibilidade de renovação apenas parcial para o Senado é um fator que assegura certa continuidade política e partidária, enquanto a oportunidade de renovação total da Câmara torna a representação na Casa mais vulnerável à instabilidade das preferências eleitorais e mais sujeita às "ondas" políticas que possam afetar os partidos ou o sistema político em geral.

Além dessas regras, que produzem incongruência na dimensão partidária da representação, a idade mínima exigida para o cargo promove a eleição de representantes com diferentes perfis e legislaturas com diferentes "temperamentos" — é esse o objetivo. Além de uma maior experiência política que pode ser acumulada ao longo da trajetória política e, assim, balizar sua atuação do senador,

9 Vale esclarecer que, contra as expectativas, nem Desposato (2003) nem Miranda (2008), que estudam o comportamento parlamentar a partir de votações nominais, nem outros autores que investigam as bases "eleitoreiras" da produção legislativa, como Ricci (2008) ou Amorim e Santos (2002), encontraram diferenças substantivas entre o comportamento de deputados e senadores. Segundo os trabalhos de Limongi e Figueiredo e Limongi (1994, 1998, 1999, 2008), essa similaridade pode ser explicada pelos fundamentos partidários da organização do trabalho legislativo no Congresso Nacional. Estes autores apelam, portanto, para variáveis internas às casas e não para variáveis classicamente associadas à análise do bicameralismo. Revela-se aqui um instigante tema de pesquisa: o impacto da organização parlamentar (em escala bicameral) sobre o funcionamento do bicameralismo brasileiro. 
desde há muito se pensa que a maturidade, que costuma vir com o tempo, se associa à sensatez e à temperança necessárias à câmara revisora, que tem, entre outras, a função de se contrapor aos eventuais arroubos primeira câmara, normalmente mais passional e propícia a escolhas intempestivas. No Brasil, por norma constitucional, a idade mínima necessária para se candidatar a senador no Brasil é quatorze anos superior à exigida para deputado federal, estadual e distrital e dezessete anos superior à exigida para vereador. Isso dá ao pleiteante à cadeira senatorial oportunidades para um maior acúmulo de experiências na vida em geral e na vida política em particular - senadores tendem a ser politicamente mais experientes e mais qualificados para o ofício da representação política do que os demais parlamentares.

De fato, segundo estudo de Llanos e Sánches (2008) sobre a 52a Legislatura (2003-2007), os senadores brasileiros são mais velhos e alcançam maiores níveis de escolaridade do que os deputados. Enquanto os primeiros têm, em média, 56,1 anos, os últimos têm 51,3; quanto ao nível de instrução, entre os senadores, 91,4\% obtiveram título universitário, ao passo que entre os deputados a taxa é de $79,1 \%$. Sobre a experiência política, os autores não apresentam dados para comparação com os deputados, mas apontam no Senado um nível compatível com as expectativas suscitadas pela teoria, pois 55,6\% dos senadores estudados já haviam sido eleitos anteriormente para mandatos na casa ou para outros cargos de peso, como presidente da república e governador de estado - cargos que, para Llanos e Sánches, sugerem grande experiência política. Em estudo sobre a composição do Senado e de sua Comissão de Constituição e Justiça, Lemos e Ranincheski (2008) apresentam dados convergentes com os acima apresentados, relativos às legislaturas iniciadas em 1991, 1995 e 1999.

Cabe mencionar, por fim, dois outros fatores importantes na estruturação da incongruência bicameral no Brasil, que presumidamente têm grande influência sobre o comportamento coletivo dos parlamentares: a duração do mandato e o número de integrantes de cada Casa. $\mathrm{O}$ fato de que o Senado é uma assembleia relativamente 


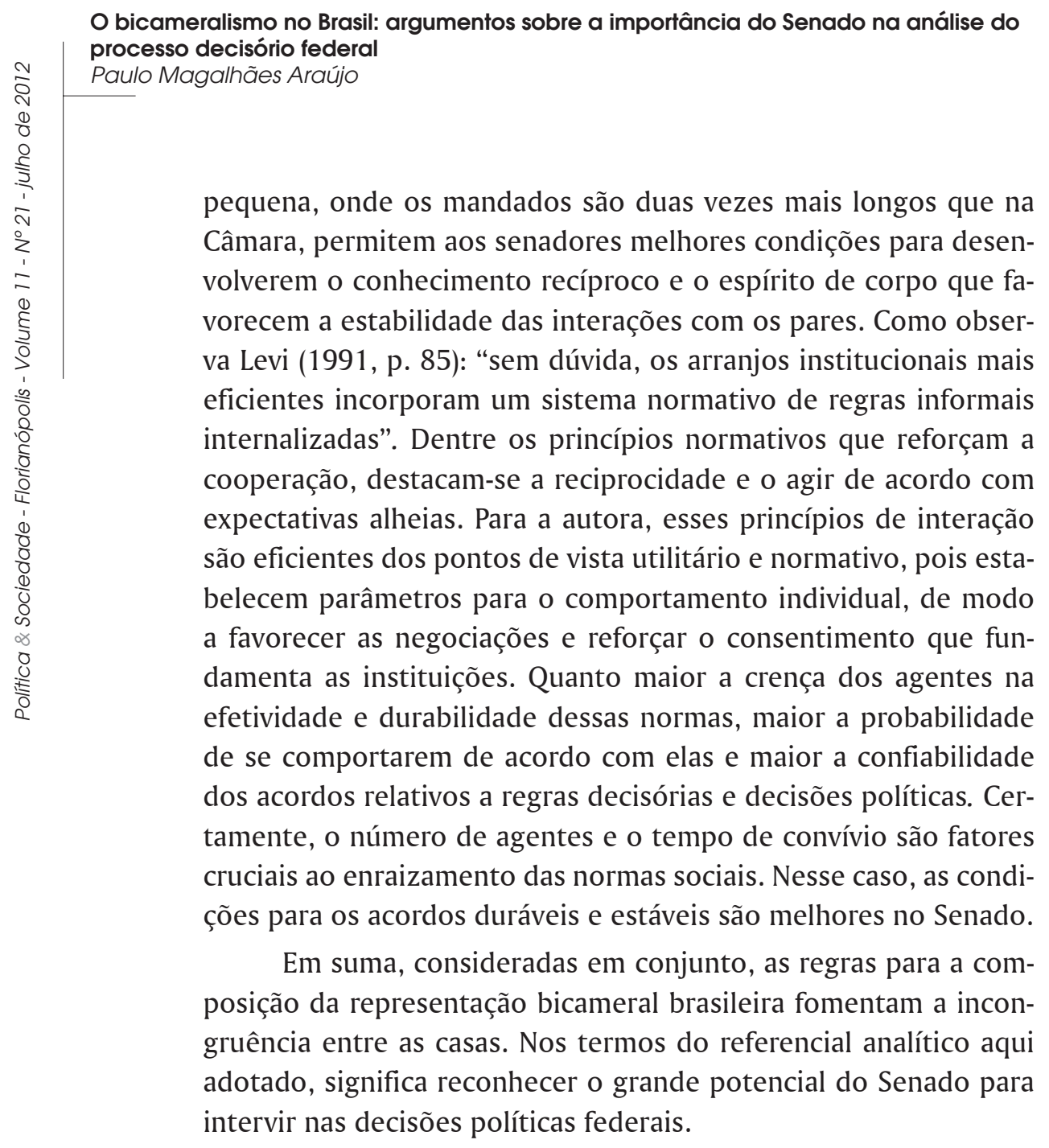

\subsection{Bicameralismo e simetria no Brasil}

Uma leitura da Constituição de 1988, incluindo as mudanças subsequentes, revela que as funções do Poder Legislativo, atinentes à proteção das instituições, ao controle das autoridades e à produção legislativa, são distribuídas de forma bastante simétrica entre o Senado Federal a Câmara dos Deputados. Não obstante, importa observar em detalhe a distribuição de tais funções, pois as competências de senadores e deputados variam conforme os 
campos de atuação parlamentar e têm efeitos importantes sobre os graus de simetria.

De início, pode-se afirmar que no Legislativo brasileiro existe um traço típico dos sistemas bicamerais. Aqui, como na maioria dos bicameralismos ao redor do mundo (NEIVA, 2006), a câmara alta se destaca pela presença nas funções de autorizar nomeações feitas pelo Executivo, investigar e julgar autoridades (vide LLANOS; LEMOS, 2008) e participar de decisões que envolvem a soberania e os interesses nacionais em questões de política internacional. No tocante estas questões, segundo Alcântara (2001), apesar da ainda tímida atuação do Congresso Nacional, a Constituição de 1988 reforçou seu papel - especialmente o do Senado - nas relações do Brasil com outras nações soberanas. $\mathrm{O}$ autor observa que, conforme os incisos IV e V do artigo 52 da Constituição Federal, cabe aos senadores aprovar a escolha dos chefes de missão diplomática de caráter permanente, bem como autorizar operações externas de natureza financeira, de interesse da União, dos Estados, do Distrito Federal, dos Territórios e dos Municípios. Como se verá adiante, esta última prerrogativa teve um importante impacto nas políticas econômicas recentes.

A Câmara dos Deputados brasileira, por sua vez, como também é comum nos sistemas bicamerais, ganha vulto por suas atribuições voltadas para a produção legislativa, especialmente naquelas matérias de interesse direto do governo.

O Quadro 2 discrimina a distribuição bicameral das funções legislativas, tipificando-as de acordo com sua influência sobre a forma da interação bicameral. Nota-se que algumas exigem a atuação coordenada das casas, outras já permitem - em termos formais - a atuação unilateral de cada uma delas. As funções foram distribuídas em três categorias: independente, dependente e coordenada. Independente quer dizer que a decisão de cada casa é formalmente livre em relação à decisão da outra; dependente, ao contrário, quer dizer que uma casa só pode decidir mediante decisão prévia da outra casa; coordenada, por sua vez, indica que a decisão bicameral final depende da coordenação simultânea das decisões de ambas as casas. Sem dúvida, o tipo de atuação permitida pelas regras afeta o poder de cada Casa e, por consequência, 
O bicameralismo no Brasil: argumentos sobre a importância do Senado na análise do processo decisório federal

Paulo Magalhães Araújo

altera a dinâmica da interação bicameral. Esses tipos são explorados adiante.

Quadro 2 - Distribuição das atribuições constitucionais que afetam a simetria do bicameralismo

\begin{tabular}{|c|c|c|c|}
\hline \multirow[t]{2}{*}{ Direitos constitucionalizados } & \multicolumn{2}{|c|}{ Prerrogativas } & \multirow[t]{2}{*}{ Tipo de decisão } \\
\hline & SF & CD & \\
\hline $\begin{array}{l}\text { Convoca autoridades, para obter } \\
\text { informações e esclarecimentos }\end{array}$ & Sim & $\operatorname{Sim}$ & Independente \\
\hline $\begin{array}{l}\text { Aprova nomeação de Juízes do Supremo } \\
\text { Tribunal Federal }\end{array}$ & Sim & Não & Independente \\
\hline $\begin{array}{l}\text { Aprova nomeação de autoridades da } \\
\text { área econômica }\end{array}$ & $\operatorname{Sim}$ & Não & Independente \\
\hline Aprova nomeação de embaixadores & Sim & Não & Independente \\
\hline $\begin{array}{l}\text { Aprova nomeação e destituição do } \\
\text { Procurador-Geral }\end{array}$ & Sim & Não & Independente \\
\hline Escolhe membros do Tribunal de Contas & $\operatorname{Sim}+$ & $\operatorname{Sim}-$ & $\begin{array}{l}\text { 2/3 coordenada; } 1 / 3 \\
\text { independente (SF) }\end{array}$ \\
\hline Fiscaliza a Administração Pública & $\operatorname{Sim}+$ & $\operatorname{Sim}-$ & $\begin{array}{l}\text { Independente ou } \\
\text { coordenada }\end{array}$ \\
\hline Controla a dívida dos estados & Sim & Não & Independente \\
\hline Cria comissões de inquérito & Sim & $\operatorname{Sim}$ & $\begin{array}{l}\text { Independente ou } \\
\text { coordenada }\end{array}$ \\
\hline $\begin{array}{l}\text { Aprova tratados e acordos } \\
\text { internacionais }\end{array}$ & Sim & $\operatorname{Sim}$ & Coordenada \\
\hline $\begin{array}{l}\text { Aprova estado de sítio e outras medidas } \\
\text { de emergência }\end{array}$ & Sim & $\operatorname{Sim}$ & Coordenada \\
\hline $\begin{array}{l}\text { Autoriza guerra e outras operações com } \\
\text { as Forças Armadas }\end{array}$ & Sim & $\operatorname{Sim}$ & Coordenada \\
\hline $\begin{array}{l}\text { Autoriza movimentação de tropas } \\
\text { estrangeiras no país }\end{array}$ & Sim & Sim & Coordenada \\
\hline $\begin{array}{l}\text { Participa dos Conselhos da Republica e } \\
\text { da Segurança Nacional }\end{array}$ & Sim & $\operatorname{Sim}$ & Independente \\
\hline $\begin{array}{l}\text { Participa de processos de impedimento } \\
\text { de autoridades }\end{array}$ & Sim & Sim & Coordenada \\
\hline $\begin{array}{l}\text { Presidente Casa substitui Presidente da } \\
\text { República }\end{array}$ & $\operatorname{Sim}-$ & $\begin{array}{l}\text { Sim } \\
+\end{array}$ & Dependente (SF) \\
\hline $\begin{array}{l}\text { Investiga ou autoriza investigação sobre } \\
\text { o Executivo }\end{array}$ & Sim & $\operatorname{Sim}$ & $\begin{array}{l}\text { Independente ou } \\
\text { coordenada }\end{array}$ \\
\hline
\end{tabular}

(Continua) 
(Continuação)

\begin{tabular}{|l|l|l|l|}
\hline \multirow{2}{*}{ Direitos constitucionalizados } & \multicolumn{2}{|l|}{ Prerrogativas } & \multirow{2}{*}{ Tipo de decisão } \\
\cline { 2 - 3 } & SF & \multicolumn{1}{|c|}{ CD } & \\
\hline $\begin{array}{l}\text { Propõe projeto de lei e emenda } \\
\text { constitucional }\end{array}$ & Sim & Sim & Independente \\
\hline $\begin{array}{l}\text { Participa da produção de legislação } \\
\text { financeira }\end{array}$ & Sim & Sim & Coordenada \\
\hline $\begin{array}{l}\text { Participa da produção de legislação não- } \\
\text { financeira }\end{array}$ & Sim - & $\begin{array}{l}\text { Sim } \\
+\end{array}$ & Coordenada \\
\hline Rejeita definitivamente projeto de lei & Sim & Sim & Independente \\
\hline $\begin{array}{l}\text { Rejeita definitivamente veto do Poder } \\
\text { Executivo }\end{array}$ & Não & Não & Coordenada \\
\hline Delibera sobre emenda constitucional & Sim & Sim & Coordenada \\
\hline $\begin{array}{l}\text { Participa da aprovação de Leis } \\
\text { Delegadas }\end{array}$ & Sim & Sim & Coordenada \\
\hline $\begin{array}{l}\text { Tem exclusividade para deliberar sobre } \\
\text { certas matérias }\end{array}$ & Sim + & Sim - & Independente \\
\hline $\begin{array}{l}\text { Propõe ou autoriza plebiscito ou } \\
\text { referendo }\end{array}$ & Sim & Sim & Coordenada \\
\hline Rejeita medidas provisórias & Sim & Sim & Independente \\
\hline Aprova medidas provisórias & Sim & Sim & Coordenada \\
\hline Convoca sessão extraordinária & Sim + & Sim - & Coordenada* \\
\hline $\begin{array}{l}\text { Toma decisão terminativa em caso de } \\
\text { impasses }\end{array}$ & Sim - & Sim & Independente \\
\hline $\begin{array}{l}\text { Participa das comissões mistas em } \\
\text { condição de igualdade }\end{array}$ & Sim & Sim & Independente \\
\hline $\begin{array}{l}\text { Participa das sessões conjuntas em } \\
\text { condição de autonomia }\end{array}$ & Sim & Sim & Independente \\
\hline $\begin{array}{l}\text { As sessões conjuntas são presididas } \\
\text { pelo presidente da Casa }\end{array}$ & Sim & Não & Dependente (CD) \\
\hline $\begin{array}{l}\text { Pode utilizar a passagem do tempo em } \\
\text { seu favor }\end{array}$ & Sim + & Sim - & Independente \\
\hline
\end{tabular}

Fonte: elaboração própria, a partir de Llanos (2002), Neiva (2006) e da Constituição Federal (1988)

[+] maior peso no exercício da função; [-] menor peso no exercício da função.

* As sessões extraordinárias para fins de produção legislativa devem ser convocadas mediante aprovação da maioria dos membros de ambas as Casas. Portanto, o uso dessa prerrogativa envolve coordenação entre as Casas. Mas, o presidente do Senado, convoca, de jure, sessões de natureza não legislativa, para, por exemplo, dar posse ao presidente ou deliberar, em Congresso, sobre decretação de estado de defesa ou de sitio. 


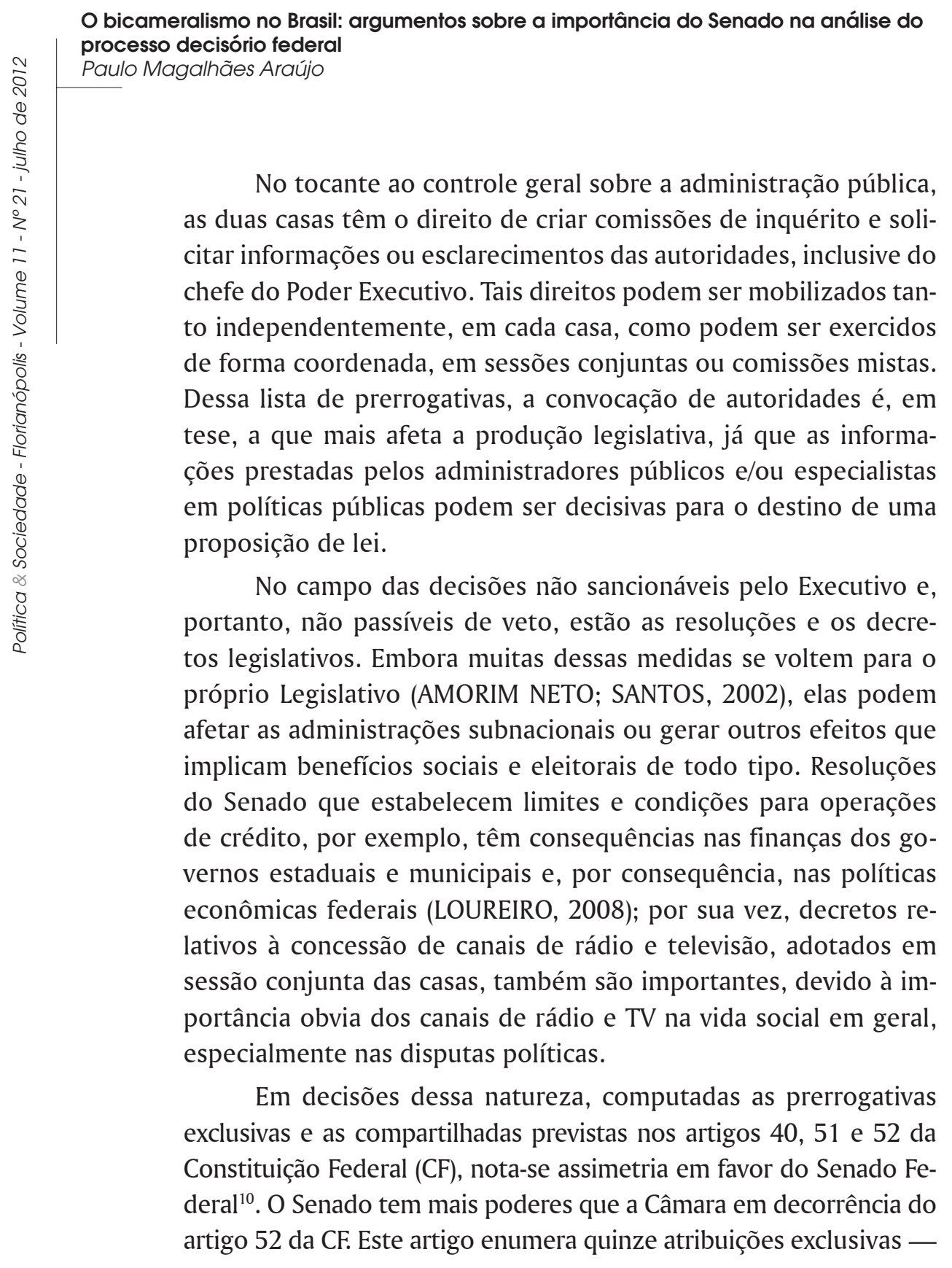

10 O artigo 51 da CF, que enumera as atribuições exclusivas da Câmara dos Deputados, contém apenas cinco incisos, dois deles se referem a atribuições voltadas para a organização da própria Casa, os outros três designam funções de controle constitucional. Dos quinze incisos do artigo 52, sobre as prerrogativas do Senado, treze são relativos aos poderes dos senadores para controlar autoridades e fiscalizar a administração pública. 
portanto independentes - do Senado, entre as quais duas podem ser destacadas: a função de avaliar periodicamente o desempenho das administrações tributárias da União, dos Estados, do Distrito Federal e dos Municípios (CF, Art. 52, inciso VIII); e o direito de estabelecer limites globais e condições para o montante da dívida mobiliária dos Estados, do Distrito Federal e dos Municípios (CF, Art. 52, inciso IX). Sobre esta questão, vale citar o estudo de Loureiro (2008), que identifica no Senado uma postura dúbia — entre a conveniência política e a racionalidade econômica - mas, no fim das contas, favorável ao ajuste fiscal e ao controle da dívida pública brasileira.

No campo de atuação atinente às questões de Estado, de governo e de defesa das instituições democráticas, o equilíbrio de forças é quase perfeito. Em primeiro lugar, quase todas as atribuições são de responsabilidade do Congresso Nacional e, portanto, exigem uma atuação coordenada das duas casas; em segundo lugar, as atribuições que não são exercidas em Congresso são bem distribuídas entre senadores e deputados. Neste último caso, cabe citar os inquéritos e processos de cassação contra os chefes do Executivo e seus ministros: havendo suspeitas graves contra qualquer desses, cabe exclusivamente à Câmara autorizar a instauração de inquérito e exclusivamente ao Senado julgar os acusados. Sendo assim, a eficácia dos controles (checks) depende da atuação convergente, mas formalmente independente, das Casas. Nessa função específica, há uma dubiedade entre a independência e a coordenação, pois há funções distintas para cada Casa, mas seu sucesso depende de um encadeamento de ações no eixo bicameral. De toda forma, há simetria.

A despeito da relevância das atribuições acima citadas, as funções diretamente relacionadas com as atividades legiferantes são em geral tidas como as mais importantes, por seu impacto forte e claro no cotidiano da sociedade nacional. No campo da produção de leis, o equilíbrio bicameral na distribuição dos direitos e funções varia conforme se comparem decisões sujeitas e não sujeitas à sanção presidencial, matérias financeiras e não 


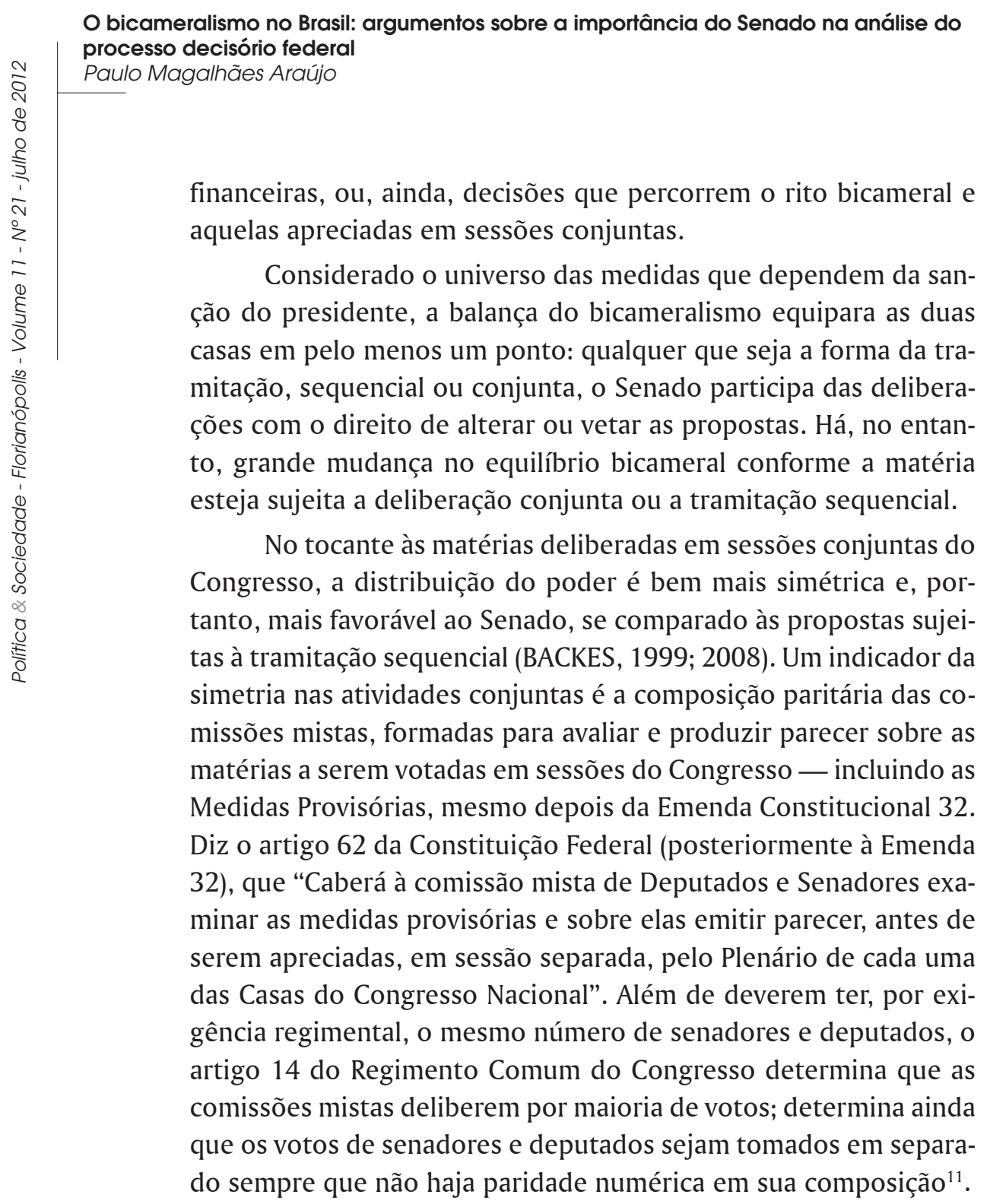

11 Em entrevista para o autor do presente texto, Marcos Evandro Santi, consultor legislativo no Senado Federal, informou que, embora previstas na etapa inicial da tramitação de Medidas Provisórias no Congresso, nesses casos as comissões mistas não são atuantes. Consta em apostila de curso sobre processo legislativo, oferecido pelo Senado: "No 15o dia [da tramitação], com ou sem parecer, a medida [provisória] vai para a Câmara dos Deputados. Se não tiver recebido parecer na comissão mista, o que tem quase sempre acontecido, este vai ser oferecido no Plenário daquela Casa.” (Disponível em: <www.senado.gov.br/ead/Conteudo/PL/Tramitacao/tramitacao13.htm>. Acesso em: 5 dez. 2011). Essa informação é reforçada por Calvalcanti (2008:, p. 52): “Na 
No caso da Comissão Mista de Planos, Orçamentos Públicos e Fiscalização (CMPOF ou CMO, como é conhecida), para a qual há um regulamento específico, as sucessivas alterações regimentais não afetaram o artigo que dispõe sobre as decisões da comissão: "As deliberações [da $\mathrm{CMO}$ ] iniciar-se-ão pelos representantes da Câmara dos Deputados, sendo que o voto contrário da maioria dos representantes de uma das Casas importará em rejeição da matéria”.

No tocante aos trabalhos do Congresso, há mais um fator que aumenta o cacife político do Senado: enquanto na tramitação sequencial os desacordos são resolvidos com a imposição da vontade da primeira Casa, nas decisões conjuntas as matérias só são transformadas em lei com o acordo simultâneo de deputados e senadores. Definida a pauta das sessões conjuntas, as duas casas se reúnem em plenário congressual sob o comando do presidente do Senado, que também preside o Congresso Nacional - exercendo, portanto, grande poder de agenda sobre as atividades conjuntas das Casas. Conforme o artigo 43 do Regimento Comum (1970), nas deliberações de plenário do Congresso, os votos da Câmara dos Deputados e do Senado Federal são sempre computados separadamente, e o voto contrário de uma das Casas implica a rejeição da matéria.

As decisões do Congresso são tomadas da seguinte forma: nas votações, os deputados votam primeiro, se rejeitarem o projeto, este será arquivado, se aprovarem, a matéria é submetida à decisão dos senadores; se os senadores rejeitarem o projeto, sua decisão é final, pois não há a possibilidade de uma segunda deliberação da Câmara, como ocorre nas tramitações com ida e volta (BACKES, 1999). Por essa norma, nas sessões conjuntas as propostas precisam ser aprovadas, na mesma sessão em rodada única de votação, por uma maioria de deputados e uma maioria de

realidade, as Comissões Mistas Especiais [para a apreciação de MPs] regulamentadas pela Resolução $\mathrm{n}^{\circ}$. 1, de 2002, praticamente não se reúnem, sendo o parecer do relator proferido diretamente em Plenário" (grifos adicionados). O fato é que a participação das Comissões Mistas na apreciação de MPs — o mais impactante instrumento legislativo do governo federal brasileiro - ainda por ser consolidada e não surte o efeito esperado na relação entre as Câmaras. 


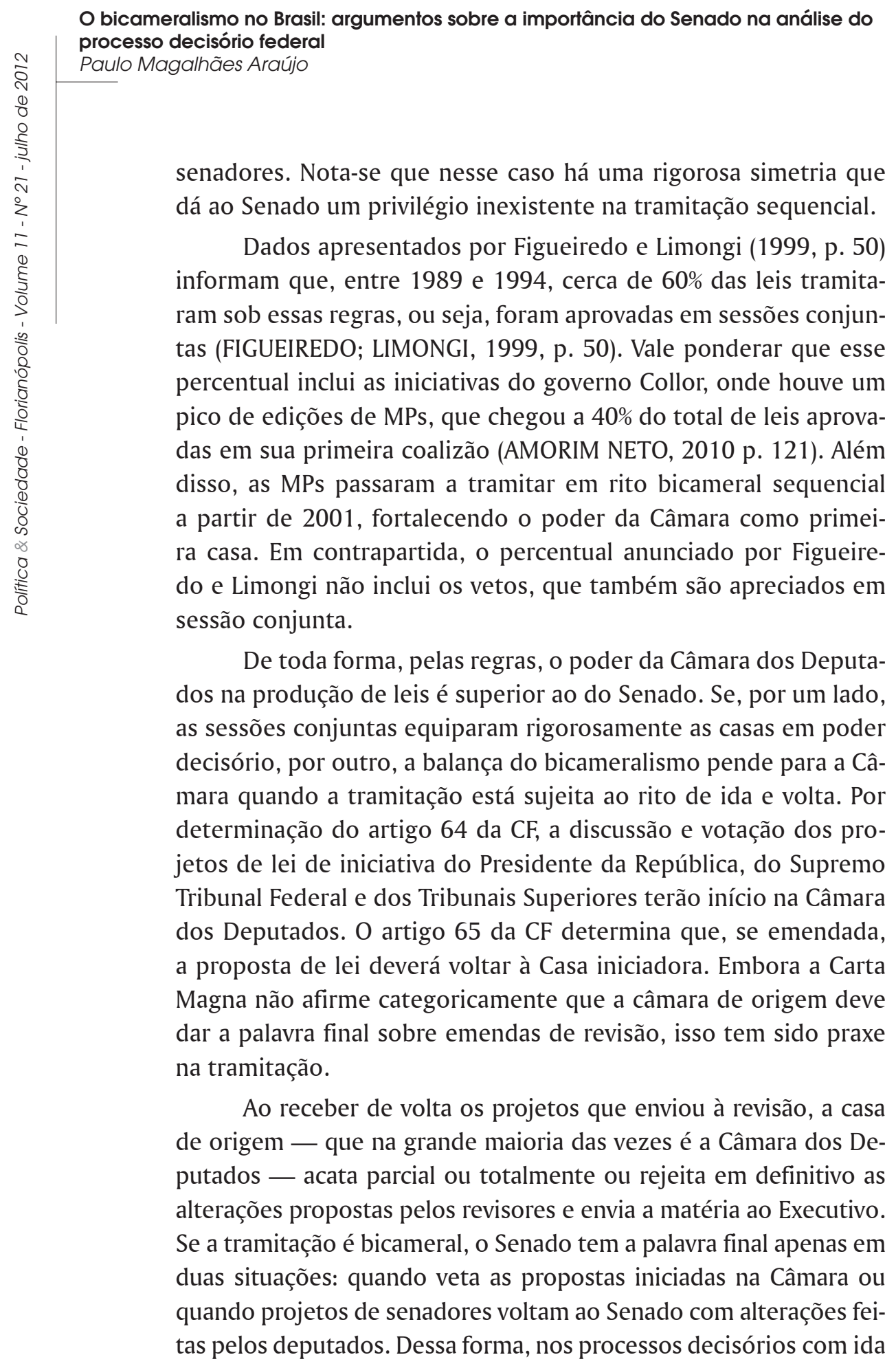


e volta, não obstante o direito do Senado para interferir nas decisões tomadas em tramitação sequencial, a Constituição assegura à Câmara um poder decisivo sobre MPs (a partir de 2001, como dito acima) e sobre projetos de lei ordinária ou complementar que tramitam pelo rito bicameral típico.

Desses traços institucionais, espera-se que o desempenho legiferante do Senado seja fortemente condicionado pela Câmara, porque as matérias já foram moldadas pelos deputados ou porque os projetos voltam à Câmara se emendadas na revisão. Mesmo no caso das deliberações conjuntas, o Senado, como segunda casa, não terá o que dizer se a Câmara rejeitar as propostas em pauta. Portanto, a proeminência da Câmara como instância de veto a coloca em melhores condições para influenciar a produção legislativa, pois seus interesses devem ser preocupação prioritária daqueles - especialmente o Executivo - que pretendem iniciar legislação. A despeito desse viés, devem ser destacados, indicadores da força do Senado, seus poderes de veto, de emendamento em revisão e de iniciativa legislativa, que são mobilizados nos jogos "aninhados" (TSEBELIS, 1998), encadeados (IMMERGUT, 1996) e contínuos (SARTORI, 1998) que envolvem a produção de leis.

Voltando ao Quadro 2, há mais uma questão acerca dos fundamentos da simetria no Brasil. O quadro mostra que sete das onze atribuições referentes às funções legiferantes são exercidas de forma coordenada, isto é, a produção de leis só ocorrerá mediante a acomodação bicameral dos interesses. Vale novamente ilustrar o argumento sobre atribuições coordenadas ou independentes: a mera iniciativa de lei não exige a coordenação entre as casas, pois uma casa não depende do aval da outra para isso; porém, a aprovação de um projeto não ocorre da mesma forma, visto que uma casa pode obstruir as escolhas da outra. No conjunto das prerrogativas ligadas à produção de leis, a simetria do bicameralismo brasileiro se manifesta não apenas nas possibilidades equilibradas de ação independente de senadores e deputados, mas, notavelmente, numa dinâmica decisória que induz ao consenso bicameral. 


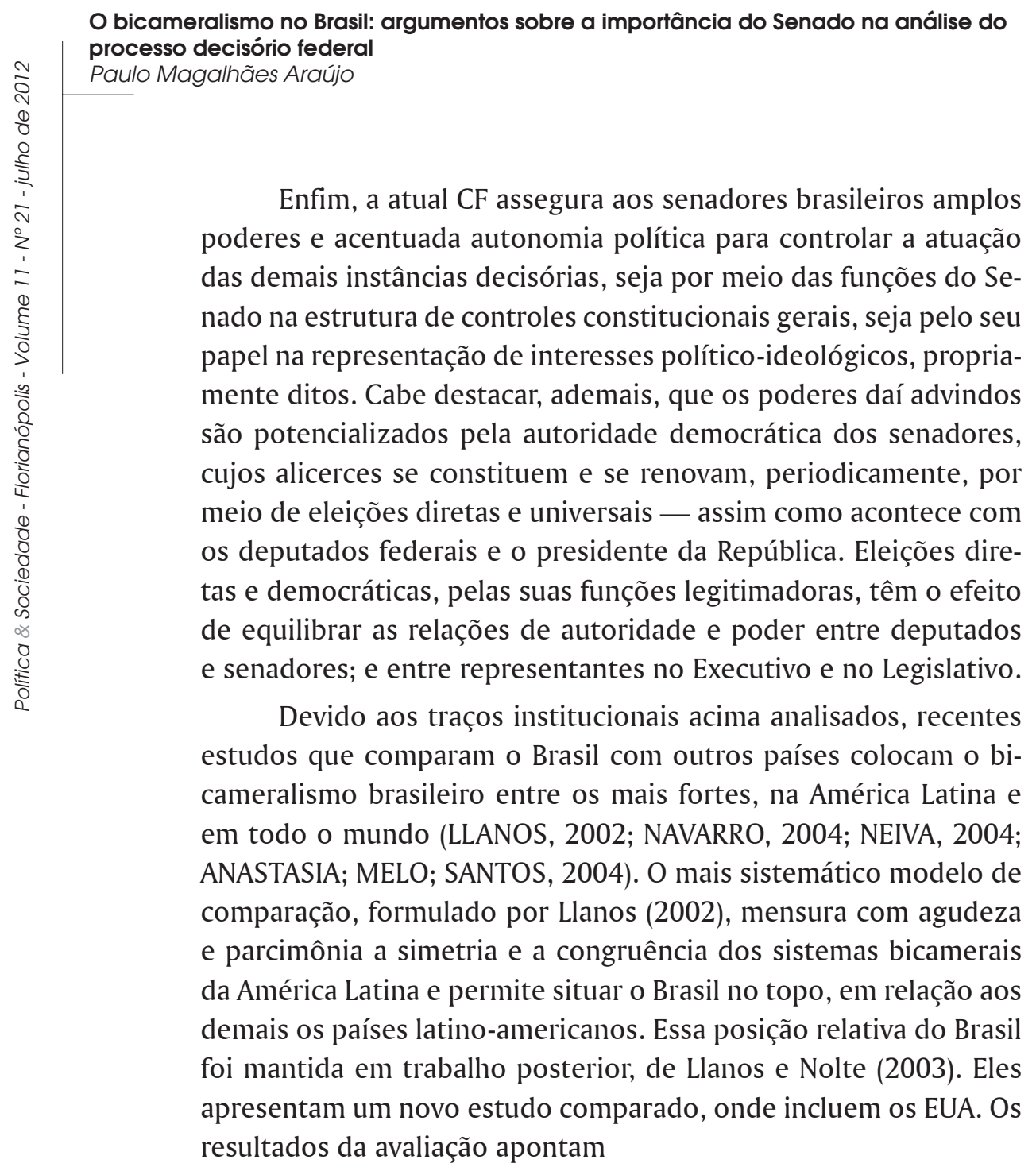

três casos - Argentina, Brasil e Estados Unidos - com os mais altos escores nas dimensões da incongruência e da simetria. Nesses países, o Senado é constitucionalmente capacitado (empowered) para agir com efetivo poder de veto. Desacordos com a Câmara dos Deputados podem ser tão comuns quanto a paralisia e o atraso na produção legislativa. O Senado também compartilha igualmente o poder com a câmara baixa para controlar o Executivo. Esses são os casos melhor qualificados para preencher os objetivos que os cientistas políticos têm associado sempre ao bicameralismo: representação de interesses diferentes [na câmara alta] daqueles representados na câmara baixa; contribuição ao sistema de freios 
e contrapesos; melhoria da qualidade da produção legislativa; e produção de resultados legislativos mais estáveis (LLANOS; NOLTE, 2006 apud GRIJÓ, 2007, p. 70. Em inglês no original, traduzido para o presente texto).

Importa lembrar ainda que o potencial político do bicameralismo brasileiro - que obviamente corresponde à força da sua Câmara Alta - se combina com o interesse manifesto dos senadores em exercitar politicamente suas funções. Llanos (2003), a partir de dados de survey, faz um estudo comparado sobre os senados argentino e brasileiro cujos resultados mostraram que, em geral, os senadores brasileiros se preocupam muito em efetivar suas funções representativas e legislativas. Em meio a uma lista de questões, o survey inquiriu os senadores sobre: (a) o quanto eles se importam com certas funções típicas do trabalho parlamentar; (b) o quanto eles consideram determinados interesses sociais ao tomar suas decisões políticas.

No tocante à primeira pergunta, as respostas obtidas indicaram que $94,9 \%$ dos senadores brasileiros "se importam" ou "se importam muito" com a representação dos interesses dos estados e 94,7\% "se preocupam" ou "se preocupam muito" em elaborar leis. Relativamente à segunda pergunta (alusiva à representação de interesses através da produção legislativa), os resultados indicaram uma forte preocupação dos senadores brasileiros em atender aos interesses de diversas categorias sociais: foi de $59,3 \%$ a taxa dos que disseram levar em conta os interesses empresariais enquanto participam de decisões políticas; $72 \%$ dos pesquisados afirmaram considerar a opinião pública em geral; 77,5\% expressaram preocupação com os eleitores do próprio estado e $64,8 \%$ disseram considerar os interesses dos governos estaduais ao participarem da produção legislativa.

Combinados o método de constituição do Senado, suas atribuições constitucionais e, ainda, as opiniões dos senadores acerca de suas próprias atividades, não restam dúvidas de que essa Casa tem recursos e incentivos de monta para influenciar tanto as decisões da Câmara dos Deputados quanto as do Poder Executivo. Esse 


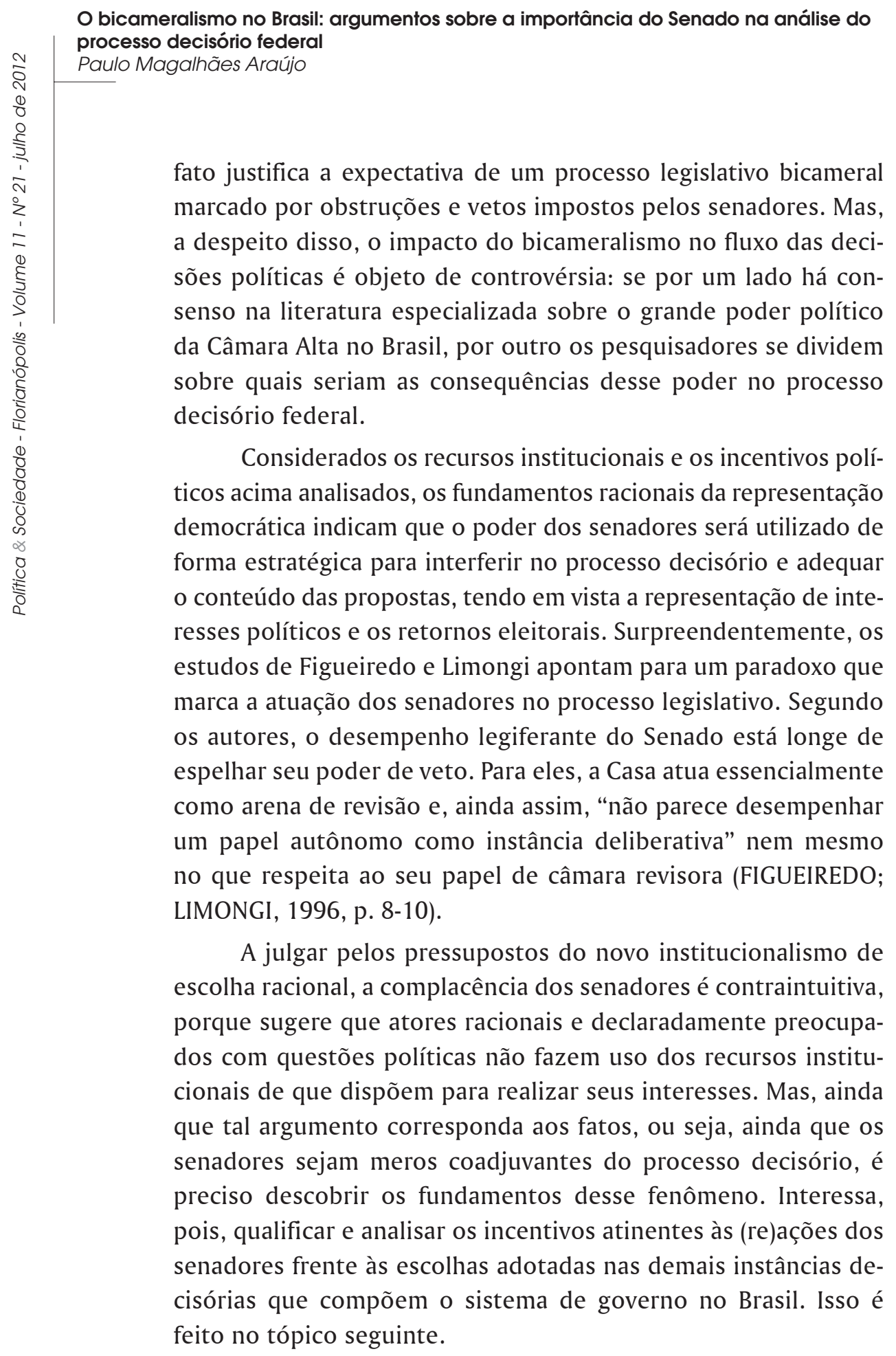




\section{O Senado no contexto do presidencialismo de coalizão}

As questões analíticas relacionadas ao desempenho do Senado no Brasil extrapolam a temática da estrutura do Poder Legislativo, stricto senso, e tocam a questão do sistema de governo. $\mathrm{O}$ Senado é uma instância decisória aninhada numa estrutura institucional mais ampla, cuja característica mais evidente é a pluralidade e a fragmentação do poder, que amplia o escopo dos consensos e aumenta as dificuldades para a tomada de decisões de interesse comum. Assim, para entender as bases institucionais do funcionamento do Senado, é preciso considerá-lo não apenas no bojo da estrutura bicameral, mas em face de outras características decisivas do sistema político.

Para alguns especialistas (AMES, 2000; MAINWARING, 1992, 1997, 2001; LINZ, 1994), a combinação institucional do presidencialismo "à brasileira" resulta num padrão decisório indesejável, porque dá excessivo poder de veto às minorias, fragmenta demais o poder político e incentiva estratégias centrífugas, levando à competição entre forças políticas que, para o bem do governo, deveriam se coalizar. Segundo Mainwaring, a combinação do presidencialismo com um sistema multipartidário fragmentado, partidos indisciplinados e um federalismo robusto, resulta em dificuldades frequentes ao governo (MAINWARING, 1997, p. 56). Com isso, as expectativas quanto ao resultado do jogo político não poderiam ser piores: irracionalidade alocativa, processos de governo truncados e entraves constantes.

Em contraponto com essa visão, há os que entendem que as causas da fragmentação do poder político - a baixa coesão dos agentes coletivos combinada com um arranjo institucional "explosivo" - encontram seu antídoto no padrão de relação entre Executivo e Legislativo combinado com o modelo de organização interna do Congresso Nacional (MENEGUELLO, 2003; SANTOS, 2003; LIMONGI; FIGUEIREDO, 1999, 2008, 2010). Os pesquisadores dessa linha de investigação argumentam que, na prática, o processo decisório é conduzido pelo Executivo e pelas lideranças 


\section{O bicameralismo no Brasil: argumentos sobre a importância do Senado na análise do processo decisório federal \\ Paulo Magalhães Araújo}

partidárias. Isso reduziria o potencial centrífugo do sistema, concentrando poderes em poucos atores, tornando-os capazes de articular acomodações de interesses e consensos entre as forças políticas relevantes. Dessa perspectiva, o todo é algo mais que a soma das partes, ou seja, o conjunto das instituições resolve os problemas de ação coletiva suscitados por instituições isoladas, promovendo um padrão decisório razoavelmente estável, ágil e eficaz para o processamento das demandas apresentadas ao sistema político.

A polêmica que envolve essas duas frentes de pesquisa tem um nível de detalhamento e riqueza que, embora de suma relevância no debate sobre instituições políticas brasileiras, não precisa ser reproduzido aqui (vide: FELISBINO, 2008; POWER, 2010). No que toca à questão central deste trabalho, essa polêmica teórica evidencia um fator institucional cuja importância é consenso entre os especialistas: a coalizão de governo. Alguns estudos questionam o argumento de que as coalizões são bases de apoio disciplinadas e confiáveis ou questionam se os ganhos de capacidade governativa que elas propiciam compensam, de fato, os custos envolvidos na sua formação e manutenção por parte do Executivo (AMES, 2000, CINTRA, 2004) ${ }^{12}$. No entanto, a partir do estudo de Abranches (1988), não se coloca em dúvida a pertinência do termo "presidencialismo de coalizão" para designar o modus operandi do sistema de governo vigente no país.

12 Além da obra citada, onde Cintra problematiza as bases da disciplina partidária e as conclusões que dela se pode extrair, o autor, ao longo de 1999 e 2000, publicou uma série de artigos no jornal $\mathbf{O}$ Tempo, de Minas Gerais, colocando em questão as conclusões de Figueiredo e Limongi. Uma das questões levantadas por Cintra, em convergência com os argumentos de Ames (2000), é de natureza metodológica. Cintra e Ames afirmam que a análise do grau de disciplina nas votações nominais não capta toda a complexidade das negociações entre Executivo e Legislativo, que se dão anteriormente às votações, e que, em tese, envolvem concessões de recursos por parte do Executivo e alterações nas suas propostas de lei, para que sejam aprovadas. Em texto recente, Figueiredo e Limongi (2010) procuram responder as críticas argumentando que no Brasil não há uma agenda dual de políticas. Aqui, como em outros sistemas baseados em coalizões governativas, haveria, segundo estes autores, negociações e concessões mútuas, por meio das quais se define uma agenda comum do Executivo e do Legislativo. A polêmica continua. 
Num contexto decisório onde o governo se sustenta, bem ou mal, sobre o apoio parlamentar de uma coalizão de partidos, tendo em vista o bicameralismo simétrico e incongruente, o aspecto bicameral da coalizão aparece como um fator de relevo para o entendimento da dinâmica decisória. Surpreendentemente, tal fator tem sido ignorado ou relegado ao segundo plano nas pesquisas empíricas sobre o tema. É preciso, pois, desenvolver modelos analíticos que considerem a influência do Senado no desempenho do Congresso, em geral, e no desempenho das coalizões de governo, em particular.

A importância do federalismo entre os elementos estruturantes do sistema político brasileiro é um fator a mais para se ter em conta o Senado nas análises do processo legislativo e da produção de leis. Na última década, muitos estudos têm mostrado a relevância dos estados (e municípios) na condução das reformas constitucionais, bem como na formulação e na implementação de programas de políticas públicas apresentados pelo governo federal (ABRÚCIO; COSTA, 1998; ARRETCHE; 1999, ANASTASIA; MELO, 2004, entre outros). Nesses processos, o Senado tem se mostrado um espaço estratégico de articulação política, onde as demandas subnacionais se representam e ajudam a conformar a dinâmica das interações das câmaras entre si e com o Poder Executivo.

Por todo o exposto, nota-se que o sistema político brasileiro - federativo, presidencialista, multipartidário e com bicameralismo simétrico e incongruente - é propício ao surgimento de impasses decorrentes de configurações partidário-ideológicas que criam arestas nas relações entre as instâncias relevantes do processo decisório.

Esse traço do sistema traz à discussão uma característica importante dos presidencialismos de coalizão, que os distingue dos sistemas bipartidários ao modo dos Estados Unidos. Estes propiciam os chamados governos divididos, isto é, situações em que o Executivo, o Senado e a Câmara não são controlados pelo mesmo partido (MAYHEW, 1991; TSEBELIS, 1995). Em contexto bipartidário, 


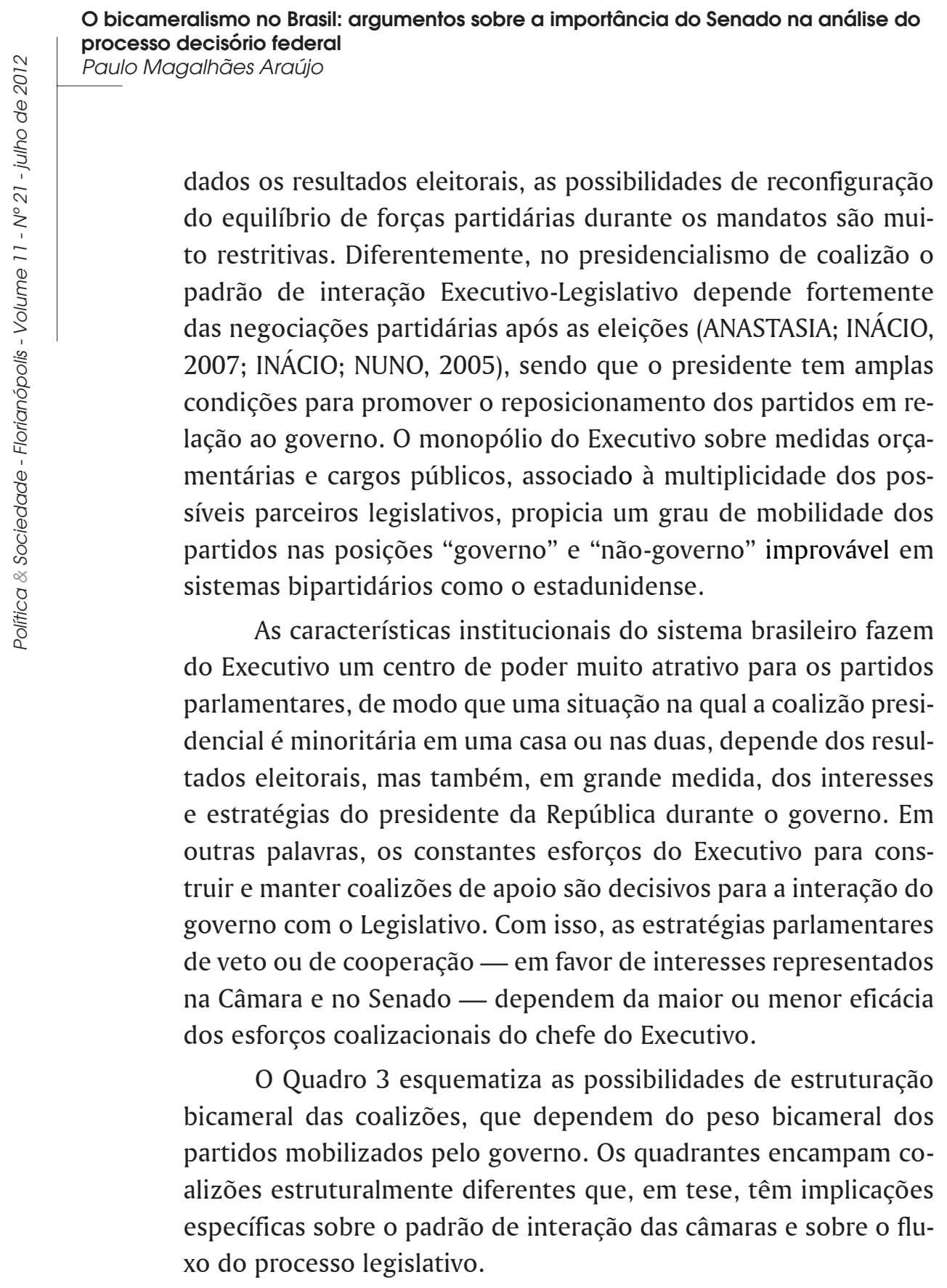


Quadro 3 - Estruturas bicamerais da coalizão, conforme o tamanho da bancada governista na Câmara e no Senado

\begin{tabular}{|c|c|c|c|}
\hline \multirow{4}{*}{ 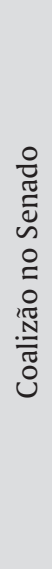 } & 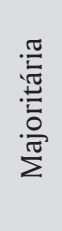 & $\begin{array}{c}1 \text { - Divergentes pró-Senado } \\
\text { (majoritárias no Senado e } \\
\text { minoritárias na Câmara) }\end{array}$ & $\begin{array}{c}2 \text { - Convergentes majoritárias } \\
\text { (bicameralmente } \\
\text { majoritárias) }\end{array}$ \\
\hline & \multirow[t]{3}{*}{ 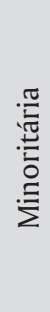 } & $\begin{array}{l}\text { 3- Convergentes minoritárias } \\
\text { (bicameralmente } \\
\text { minoritárias) }\end{array}$ & $\begin{array}{l}\text { 4- Divergentes pró- Câmara } \\
\text { (majoritárias na Câmara e } \\
\text { minoritárias Senado) }\end{array}$ \\
\hline & & Minoritária & Majoritária \\
\hline & & Coalizão & a Câmara \\
\hline
\end{tabular}

Fonte: Elaboração própria, 2009

Por hipótese, controladas as demais variáveis, as coalizões situadas no quadrante 1 , divergentes, majoritárias no Senado e minoritárias na Câmara, criam maior dificuldade para a interação do governo com os deputados que com os senadores, pois entre estes não será necessário buscar apoio em partidos fora da base governista, mas o governo deverá enfrentar dificuldades, caso uma matéria de seu interesse seja iniciada por um senador. O quadrante 2 , com coalizões convergentes, bicameralmente majoritárias, oferece o melhor cenário para o Executivo, já que a oposição pode ser derrotada pelo voto em qualquer das Casas. Situar-se no terceiro quadrante, com bases bicameralmente minoritárias, é uma condição que gera mais imprevisibilidade na interação dos poderes, pois a aprovação das matérias tende a depender de entendimentos ocasionais (ad hoc) entre Executivo e Legislativo em ambas as casas. Com uma base parlamentar desse tipo, provavelmente surgem mais situações em que o Executivo precisa ceder no conteúdo das matérias ou cooptar apoio por meio de recursos de patronagem 


\section{O bicameralismo no Brasil: argumentos sobre a importância do Senado na análise do processo decisório federal \\ Paulo Magalhães Araújo}

(ANDRADE, 1998; PEREIRA; RENNÓ, 2001). Por fim, há o último quadrante, que abrange coalizões divergentes, majoritárias apenas na Câmara. Nesse caso, em bicameralismos simétricos, os projetos governistas deverão ter revisões mais conflituosas, já que senadores da oposição precisam ser induzidos a apoiar o governo.

Fica claro que, se o funcionamento do presidencialismo brasileiro é pensado tendo em vista as possibilidades bicamerais das coalizões em um Estado federativo, o Senado se torna uma instância decisória de crucial importância política e, por consequência, também analítica. Para que os projetos do Executivo ou do próprio Legislativo sejam aprovados, o potencial de apoio das coalizões precisa ser reforçado em escala bicameral e o poder de veto das oposições precisa ser superado por meio de manobras regimentais ou acordos políticos, estáveis ou ad hoc, que perpassem as duas casas legislativas. Por outras palavras, para diminuir os riscos de fracasso do governo, as coalizões de apoio precisam abranger as duas casas e controlar o processo decisório em todo o eixo bicameral, para levarem a cabo a aprovação das propostas sem permitir o desvirtuamento do seu conteúdo ${ }^{13}$.

Se por um lado se espera que os graus de dificuldades para o acordo bicameral variem conforme a estrutura bicameral das coalizões, por outro se entende que, qualquer que seja o perfil da representação congressual, a atuação das lideranças partidárias na Câmara e no Senado é ser crucial na coordenação das estratégias legislativas intercamerais. Ademais, as articulações pré e pós-eleitorais do (candidato ao) governo com vistas à conformação do apoio parlamentar também têm impacto decisivo no perfil e

13 A preocupação dos governos com relação a esse problema fica clara quando se considera a estrutura das coalizões governativas montadas após 1988. Das 21 coalizões listadas em Araújo (2011), 14 foram bicameralmente majoritárias, 1uma foi majoritária apenas na Câmara (a quarta coalizão do primeiro governo Lula), outra majoritária apenas no Senado (a segunda do governo Itamar), cinco foram bicameralmente minoritárias (as três montadas por Collor, a última do segundo governo FHC e a primeira do primeiro governo Lula). Apenas Collor governou com coalizões minoritárias nas duas casas durante todo o (encurtado) mandato. Fernando Henrique Cardoso, Lula e Itamar Franco tiveram bases minoritárias em caráter circunstancial e transitório. 
na dinâmica do governo de coalizão (ANASTASIA; INÁCIO, 2007). As estratégias de formação de coalizões adotadas pelo governo se tornam um dilema contínuo, com implicações relevantes sobre o grau de cooperação ou competitividade entre as duas câmaras e entre elas e o Poder Executivo.

Neste ponto emerge uma questão importante deste artigo, ainda não devidamente considerada nos estudos sobre o padrão de atuação do Senado Federal no processo decisório. A despeito da polarização existente no debate acadêmico, defende-se que o Senado não precisa ser visto como um ponto de veto recalcitrante ou como um "carimbador" de decisões externas. Pressupondo-se o caráter racional e, portanto, condicional das suas escolhas, é plausível esperar que seu desempenho seja afetado fatores variáveis, tais como a configuração partidária da representação, a distribuição de poder na organização parlamentar, as estratégias do governo e o contexto político federal que emoldura a efetiva tomada de decisões.

Levando-se em conta as bases partidárias da organização parlamentar no Congresso (SANTOS, 2003; ARAÚJO, 2010; FIGUEIREDO; LIMONGI, 1999; 2010), a configuração bicameral da representação deve ser considerada uma variável central para a análise do Senado. Ela impacta diretamente a distribuição de poder na estrutura legislativa e, por suposto, condiciona, em escala bicameral, a natureza das parcerias parlamentares, bem como as possibilidades estratégicas do governo em suas investidas para a constituição de uma base de apoio voltada à aprovação de seu programa. Além disso, mesmo a tramitação de matérias não conectadas diretamente à agenda do governo pode ser afetada pela configuração político-partidária da representação parlamentar "bicameralizada" por exemplo: discrepâncias intercamerais no peso dos partidos ou blocos partidários podem afetar a complexidade das negociações entre as Câmaras, impactando o ritmo da tramitação e o conteúdo dos projetos em geral, e não apenas os do Executivo.

Supõe-se, enfim, que o grau de sucesso dos líderes parlamentares e do próprio Executivo em controlar o comportamento 


\section{O bicameralismo no Brasil: argumentos sobre a importância do Senado na análise do processo decisório federal \\ Paulo Magalhães Araújo}

dos senadores e coordenar os acordos legislativos será mais bem entendido se observada a estruturação das forças partidárias contidas no Parlamento. Suponha-se uma situação muito favorável, em que o governo dispõe, nas duas casas, de uma base majoritária — e também pouco fragmentada e ideologicamente homogênea ${ }^{14}$. Nesse caso, a simetria bicameral tenderá a não ser um obstáculo, porque a influência de tal coalizão perpassará o sistema bicameral e mitigará o poder de veto das minorias em ambas as câmaras. Com isso, reduz-se o potencial de obstrução de uma casa sobre as decisões da outra. Já em condições desfavoráveis para o governo, o bicameralismo deverá implicar obstruções à aprovação dos projetos em tramitação: um projeto apoiado por coalizões bicameralmente incongruentes - e também internamente fragmentadas e heterogêneas - , enfrentará mais resistência e sua tramitação tenderá a ser mais obstruída. Em suma, as características bicamerais da representação deverão impactar o padrão de conflito intra e entre câmaras e, portanto, alterar a dinâmica de atuação do Senado no processo bicameral.

Alguns aspectos desse argumento foram testados, com resultados positivos (vide: HIROY, 2008; ARAÚJO, 2009; 2011). Nos estudos de Araújo, analisaram-se dados relativos à tramitação de projetos de lei e de emendas constitucionais iniciados no período $1989-2010^{15}$, com vistas a verificar o efeito de variáveis relativas à composição político-partidária do Congresso (entre outras) sobre as chances de um projeto ser alterado pelos senadores. A autoria dos projetos, seu conteúdo, abrangência e o regime de tramitação adotado na sua apreciação foram algumas das variáveis de controle

14 Essas variáveis dizem respeito às características endógenas da representação, seja a legislatura como um todo, sejam os blocos parlamentares. Estudos mostram que, quando maior a fragmentação e a heterogeneidade dos grupos parlamentares, maior as dificuldades destes para formarem consensos e atuarem como atores coletivos efetivos (cf. ALTMAN; PÉREZ LIÑÁN, 2001; GARCÍA-DIEZ; BARAHONA, 2002; INÁCIO; NUNO, 2005; INÁCIO, 2006).

15 Um estudo (ARAÚJO, 2009) abordou todos os projetos apreciados no período 19892004, que receberam parecer conclusivo dos senadores; o outro (ARAÚJO, 2011), considerou apenas projetos do Executivo, ingressados no Senado entre 1989 e 2010. 
utilizadas. Como variáveis explicativas, os testes estatísticos incluíram indicadores relativos à composição partidária do Senado e aos graus de divergência partidário-ideológica entre as casas e entre as coalizões de uma casa frente às da outra. No geral, os resultados mostraram correlações significativas e na direção esperada, mostrando que a disposição dos senadores para emendar os projetos é variável dependente da conformação da representação senatorial, em particular, da representação bicameral, como um todo (ARAÚJO, 2009; 2011).

O estudo feito por Hiroy (2011) parte de premissas parecidas e chega a conclusões convergentes, no tocante ao caráter interdependente do desempenho do Senado e da Câmara. A análise explora variáveis que, por hipótese, condicionam o desempenho do legislativo bicameral brasileiro e conclui que coalizões bicameralmente majoritárias aumentam as chances de aprovação dos projetos, enquanto a incongruência bicameral aumenta o risco de rejeição dos projetos ou atrasam sua tramitação.

No momento, não se tem conhecimento de outros estudos que analisem o desempenho do Congresso Nacional no processo legislativo, tendo em vista as variáveis institucionais e político-partidárias que conformam o bicameralismo interconectando a atuação do Senado e da Câmara. Esta é uma frente nova de pesquisa que está por ser explorada e que pode contribuir para um entendimento mais consistente do funcionamento do bicameralismo e de cada uma das casas, como também das relações entre Executivo e Legislativo no Brasil e das decisões políticas que daí resultam.

Enfim, este texto é uma tentativa de apresentar argumentos, e alguns dados, que evidenciem a importância política do Senado brasileiro em face da estrutura bicameral vigente, por sua vez assentada no bojo do presidencialismo de coalizão. O objetivo principal dos argumentos aqui expostos é o de explicitar um ponto crucial a ser considerado nas análises do Congresso: em um sistema de tal complexidade, não basta considerar cada instância decisória de forma estanque e isolada, mas como parte de uma estrutura institucional maior, marcada por uma rede de interdependência que 


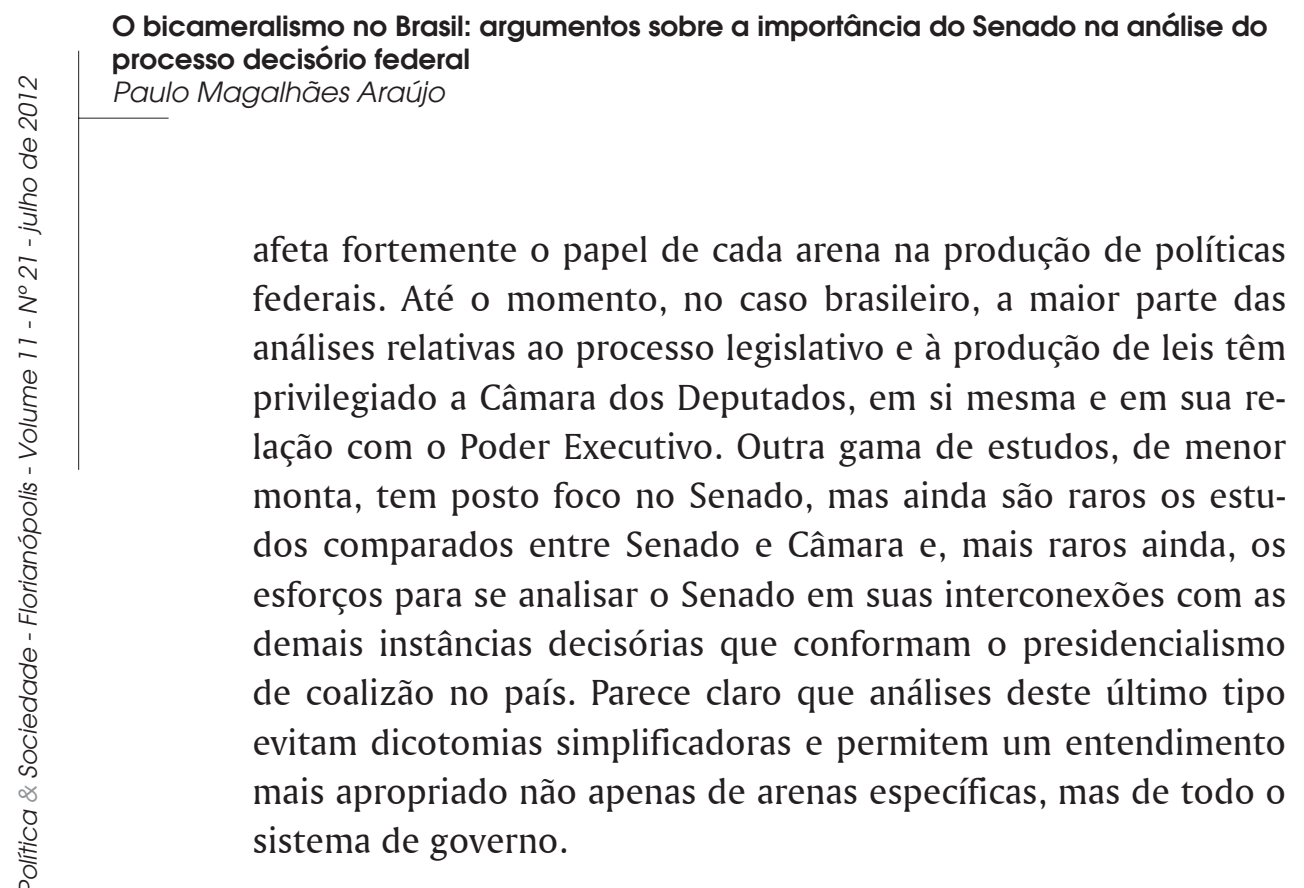

\section{Considerações finais}

Com base nas teorias correntes sobre sistemas bicamerais, o trabalho analisou a força do sistema bicameralismo brasileiro, comparando as casas em termos das regras de composição e do poder político de cada uma. Foi considerada também a posição das casas no sistema de divisão de poderes entre Executivo e Legislativo e o papel das coalizões governistas nas relações entre esses poderes divididos. A análise permite duas conclusões importantes sobre a influência do Senado Federal na produção de leis, tendo em vista sua posição no sistema bicameral e o padrão dominante de interação entre Executivo e Legislativo no Brasil.

A primeira conclusão se refere à estrutura do bicameralismo. No tocante à distribuição bicameral do poder, conclui-se que o Senado se equipara à Câmara em termos das respectivas listas de atribuições constitucionais legiferantes e extralegiferantes, ainda que os graus de simetria entre elas variem conforme os campos de atuação política. No tocante à composição das duas casas, ficaram claras as bases institucionais da divergência no perfil político-partidário de deputados e senadores. Sem dúvida, a simetria e a 
incongruência observadas na análise indicam que os senadores não só têm um acentuado poder político como atuam sob padrões de incentivos distintos dos que estão sujeitos os deputados. Essa combinação institucional resulta em força do bicameralismo para cumprir, nos termos de Tsebelis e Money (1997), suas funções "política" e "de eficiência", tornando muito prováveis as situações em que a mobilização política dos senadores seja necessária para confrontar ou complementar acordos previamente definidos na Câmara.

No campo das atribuições legislativas relacionadas com a produção de políticas, ficou claro que a Câmara tem maior controle sobre as deliberações, especialmente quando as proposições estão sujeitas às idas e voltas bicamerais que, a partir da PEC 32, que mudou a tramitação das MPs, compõem a maior parte das propostas apreciadas. Nestes casos, por determinação constitucional, os deputados são quase sempre os responsáveis pela primeira rodada de negociações; sendo que, se os projetos são alterados pelos senadores, os deputados têm ainda a chance de dar a última palavra, acatando ou não as mudanças feitas em revisão. Por isso, na maior parte das vezes, a única chance de o Senado dar a palavra final é vetando os projetos previamente aprovados na Câmara, mas essa decisão nem sempre é possível, devido ao caráter dramático das escolhas: em certos casos, os custos de uma rejeição total podem ser altos demais para serem assumidos pelos senadores.

A despeito desse viés assimétrico em favor da Câmara, o Senado tem grande influência sobre o processo legislativo e sobre o conteúdo da legislação, seja porque também pode iniciar projetos - caso em que ele passa a ter o direito à ultima palavra seja porque as decisões políticas se dão de forma encadeada, em fluxo contínuo, permitindo negociações cruzadas, que mantêm o poder dos senadores mesmo nas decisões sobre matérias em que, formalmente, o Senado não pode mais interferir.

O certo é que, em decorrência da simetria e da incongruência típicas do bicameralismo brasileiro, o potencial legiferante do Senado vai muito além de sua função de eficiência, que promove o aprimoramento da legislação, e toca na essência das questões 


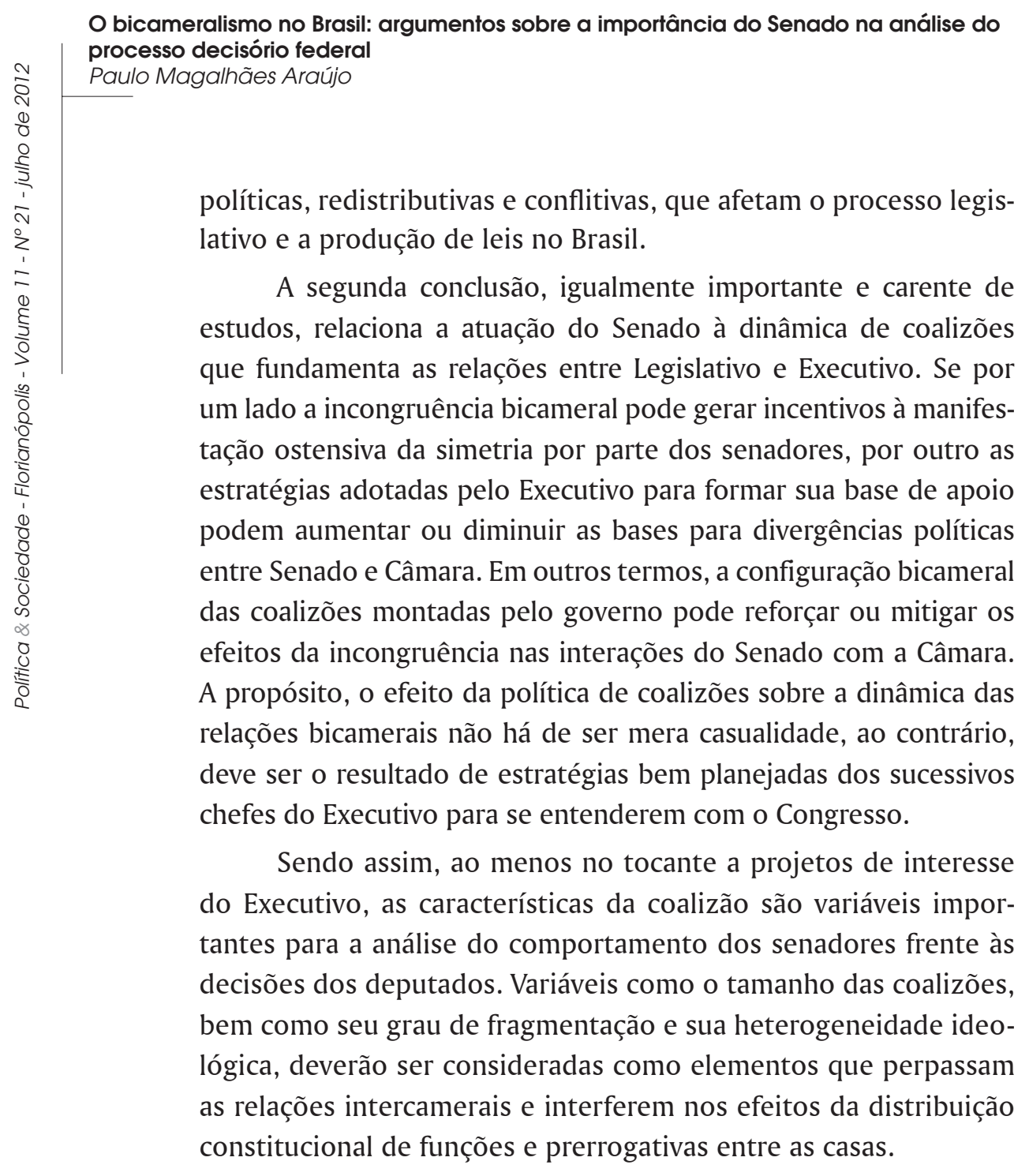

\section{Referências}

ABRANCHES, S. Presidencialismo de Coalizão: o dilema institucional brasileiro. Dados - Revista de Ciências Sociais, Rio de Janeiro, v. 31, p. 5-38, 1988.

ABRÚCIO, F. L. Os Barões da Federação: os governadores e a redemocratização. São Paulo: HUCITEC, 1998. 
ABRÚCIO, F. L; COSTA, V. F. Reforma do Estado e o contexto federativo brasileiro. São Paulo: Fundação Konrad Adenauer, 1998.

ALTMAN, G. A. e PEREZ-LINAN, A. Assessing the Quality of Democracy: freedom, competitiveness and participation in 18 latin american countries. Kellogg Institute, Notre Dame University, Notre Dame, 2001.

AMES, B. The Deadlock of Democracy in Brazil. Ann Arbor: Michigan University Press, 2000.

AMORIM NETO, O.; SANTOS, F. A Produção Legislativa do Congresso: entre a paróquia e a nação. In: Luiz Werneck Vianna (Org.). A Democracia e os Três Poderes no Brasil. Rio de Janeiro, IUPERJ/FAPERJ, 2002.

ANASTASIA, F; MELO, C. R. "Accountability, Representação e Estabilidade Política no Brasil". In: ABRUCIO e LOUREIRO (Orgs.). O Estado numa era de reformas: os anos FHC. Ministério do Planejamento, 2003. Disponível em: <http:/www.planejamento. gov.br/secretarias/upload/Arquivos/seges/PMPEF/publicacoes/ manuais_doc/081016_PUB_ManDoc_estado1.pdf $>$. Acesso em: 10 set. 2011.

ANASTASIA, F.; MELO, C. R.; SANTOS, F. Governabilidade e Representação Política na América Latina. Rio de Janeiro: Fundação Konrad Adenauer; São Paulo: Unesp, 2004.

ANASTASIA, F. e INÁCIO, M. Notas sobre coalizões políticas e democracia: diz-me com quem andas... Trabalho apresentado no Seminário Internacional Estudos Sobre o Legislativo. Brasília: UnB - Câmara dos Deputados, Set. 2007.

ANDRADE, R. C. (Org). O Processo de Governo no Município e no Estado: uma análise a partir de São Paulo. São Paulo: EDUSP, 1998.

ARAÚJO, P. M. Argentina, Brasil e Vezuela: aspectos institucionais dos sistemas federativos na América do Sul. Revista Teoria e Sociedade, n. especial (Instituições Políticas e Democracia na América do Sul), 2005. 


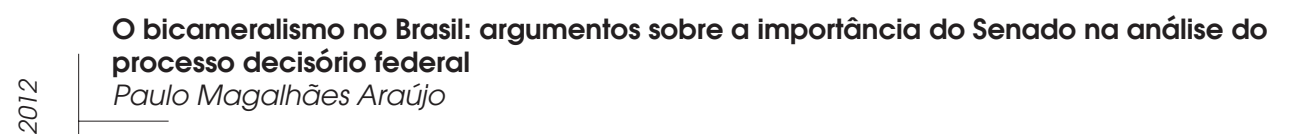

ARAÚJO, P. M. O bicameralismo no Brasil: as bases políticas e institucionais do desempenho legislativo do Senado (19892004). Belo Horizonte. Tese (Doutorado em Ciência Política) Universidade Federal de Minas Gerais, UFMG, 2009.

ARAÚJO, P. M. O Bicameralismo e o Poder Executivo no Brasil: revisão de projetos presidenciais entre 1989-2010. Trabalho apresentado no Primeiro Encontro do Grupo de Estudos Legislativos da ALACIP. Belo Horizonte, 2011. (impresso por computador).

ARRETCHE, M. Políticas Sociais no Brasil. Descentralização em um Estado Federativo. Revista Brasileira de Ciências Sociais, v. 14, 1999.

BACKES, Ana Luiza. Democracia e sobre-representação de regiões: o papel do Senado. Dissertação (Mestrado em Ciência Política) Universidade de Brasília, 1999.

BACKES, Ana Luiza. Fortalecimento parlamentar de minorias regionais e suas razões. In: LEMOS, Leany Barreiro (Org.). O Senado Federal no Pós-constituinte. Brasília: Senado Federal, Unilegis, 2008.

BRASIL. CONGRESSO. CÂMARA DOS DEPUTADOS. Regimento Interno: Resolução n. 17, de 1989. Brasília: Câmara dos Deputados, 2006. Texto editado em conformidade com a Resolução n. 18, de 1989, consolidado com as alterações decorrentes de emendas à Constituição, leis e resoluções posteriores, até 2006.

BRASIL. CONGRESSO. SENADO FEDERAL. Regimento Interno [e normas conexas]: Resolução n. 93, de 1970. Brasília: Senado Federal, 2007. Texto editado em conformidade com a Resolução n. 18, de 1989, consolidado com as alterações decorrentes de emendas à Constituição, leis e resoluções posteriores, até 2006.

BRASIL, CONSTITUIÇÃO FEDERAL DE 1988. Brasília: Impressa no Senado Federal. Texto consolidado até a Emenda Constitucional n. 52, de 8 de março de 2006.

CAMPOS, M. M. Democracia, partidos e eleições: os custos do sistema partidário-eleitoral no brasil. Belo Horizonte. Tese 
(Doutorado em Ciência Política) - Universidade Federal de Minas Gerais, UFMG 2009.

CAVALCANTI, M. R. C. Medidas provisórias e sua tramitação por uma única comissão mista permanente: uma análise crítica. Monografia (especialização) - Curso de Processo Legislativo, Câmara dos Deputados, Centro de Formação, Treinamento e Aperfeiçoamento (Cefor), 2008. Disponível em: < http://bd.camara. gov.br/bd/bitstream/handle/bdcamara/4183/medidas_provisorias _ cavalcanti.pdf?sequence =1> . Acesso em 5 dez. 2011 .

CINTRA, A. O. O Sistema de Governo no Brasil. In: CINTRA, A. O.; AVELAR, L. Sistema Político Brasileiro: uma introdução. Rio de Janeiro: Fundação Konrad Adenauer/ São Paulo: Unesp, 2004.

DESPOSATO, S. Could SMD Solve Brazil's Political Problems? A comparison of the brazilian Senate and Chamber of Deputies. Working Paper, 2002.

DUVERGER, M. Os partidos Políticos. Brasília: UnB, 1980.

FELISBINO, R. A atuação dos partidos políticos na câmara dos deputados: alguns comentários dos estudos legislativos no Brasil. Revista Achegas, n. 37, 2008. Disponível em: <www.achegas.net/ numero/37/riberti_37.pdf>. Acesso em: 20 nov. 2011.

FIGUEIREDO, A.; LIMONGI, F. O processo legislativo e a produção legal no congresso pós-constituinte. Novos Estudos - CEBRAP, São Paulo, n. 38, p. 24-37, 1994.

FIGUEIREDO, A.; LIMONGI, F. Congresso Nacional: organização, processo legislativo e Produção Legal. Caderno de Pesquisas CEBRAP/Entrelinhas, São Paulo, n. 5, 1996.

FIGUEIREDO, A.; LIMONGI, F. Executivo e Legislativo na Nova Ordem Constitucional. Rio de Janeiro: FGV, 1999.

FIGUEIREDO, A.; LIMONGI, F. Política Orçamentária no Presidencialismo de Coalizão. Rio de Janeiro: FGV, 2008. 


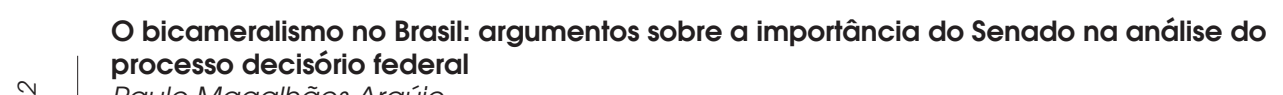
Paulo Magalhães Araújo

FIGUEIREDO, A.; LIMONGI, F. Poder de Agenda e Políticas Substantivas. IGNÁCIO, M.; RENNÓ, L. Legislativo Brasileiro em Perspectiva Comparada. Belo Horizonte, UFMG, 2010.

GARCÍA DIEZ, F.; BARAHONA, E. M. La estratégia política e parlamentaria de los partidos de oposición latinoamericanos: ¿capacidade de influência ou influência efetiva? In: Revista Instituciones y Desarrollo, n. 12-13. Institut de Governabilitat de Catalunya, Barcelona, 2002.

HAMILTON, A.; MADISON, T.; JAY, J. O Federalista. Coleção Os pensadores. São Paulo: Abril Cultural, 1979.

IMMERGUT, E. As regras do jogo: a lógica da política de saúde na França, na Suíça e na Suécia. Revista Brasileira de Ciências Sociais, v. 30, n. 11, p.139-163, 1996.

INÁCIO, M. Presidencialismo de coalizão e sucesso presidencial na arena legislativa 1990-2004. Tese (Doutorado em Ciências Humanas) - Universidade Federal de Minas Gerais, Belo Horizonte, 2006.

INÁCIO, M.; NUNO, A. Competição política e estabilidade sob o presidencialismo de coalizão na América do Sul. Revista Teoria e Sociedade, n. Especial: Instituições Políticas e Democracia na América do Sul. Belo Horizonte: UFMG, 2005.

AMORIM NETO, O. O Brasil, Lijphart e o modelo consensual de democracia. In: IGNÁCIO, M.; RENNÓ, L. Legislativo brasileiro em perspectiva comparada. Belo Horizonte, UFMG, 2010.

LEMOS, L. B. (Org.). O Senado Federal no pós-constituinte. Brasília: Senado Federal, Unilegis, 2008.

LEMOS, L. B.; RANINCHESKI, S. Carreiras políticas no Senado brasileiro: um estudo das composições do plenário e da Comissão de Justiça e Cidadania na década de 1990. In: LEMOS, L. B. (Org). O Senado Federal no pós-constituinte. Brasília: Senado Federal, Unilegis, 2008. 
LEVI, M. Uma Lógica da Mudança Institucional. In: Dados, Rio de Janeiro, v. 34, n. 1, 1991.

LIJPHART, A. As democracias contemporâneas. Gradiva: Lisboa, 1989.

LIJPHART, A. Modelos de Democracia: desempenho e padrões de governo em 36 países. Rio de Janeiro: Civilização Brasileira, 2003.

LINZ, J. Presidential or Parliamentary Democracy: Does it Make a Diference?, In: LINZ, J. J.; VALENZUELA A. (Eds.). The failure of presidential democracy: the case of Latin America (v. 2). Baltimore, The Johns Hopkins University Press, 1994.

LLANOS, M. El Bicameralismo en América Latina. Arbeitspapier n. 5. Hamburg: Institut für Iberoamerica-Kunde, 2002. Disponível em: $\quad<$ http://www.juridicas.unam.mx/publica/librev/rev/dconstla/ cont/2003/pr/pr20.pdf > . Acesso em: 3 dez. 2011.

LLANOS, M.; NOLTE, D. Bicameralism in the Americas: around the extremes of symmetry and incongruence. In: The Journal of Legislative Studies, v. 9, n. 3, autumn, p. 54-86, 2003.

LLANOS M.; SANCHES, F. Conselho de Anciãos? O Senado e seus membros no Cone Sul. In: LEMOS, L. B. (Org.). O Senado Federal no pós-constituinte. Brasília: Senado Federal, Unilegis, 2008.

LOUREIRO, M. R. O Senado e o controle do endividamento público no Brasil. In: LEMOS, L. B. (Org.). O Senado Federal no pósconstituinte. Brasília: Senado Federal, Unilegis, 2008.

MAINWARING, S. Presidentialism in Latin America. In: Arend Lijphart (Ed.). Parliamentary versus Presidential Government. Oxford University Press, 1992.

MAINWARING, S. "Multipartism, Strong Federalism, and Presidentialism in Brazil." In Scott Mainwaring and Matthew Soberg Shugart (Eds.). Presidentialism and democracy in Latin America. New York and Cambridge: Cambridge University Press, 1997, p. 55-109. 


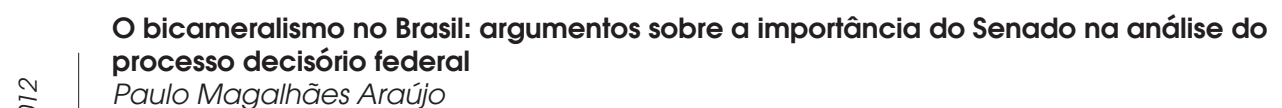
Paulo Magalhães Araújo

MAINWARING, S. Sistemas Partidários: o caso do Brasil. Rio de Janeiro: FGV, 2001.

MAINWARING, S.; SHUGART, M. Presidentialism and democracy in Latin América. Cambridge University Press, 1997.

MASSICOTTI, L. Legislative Unicameralism: a global Survey and a Few Case Studies. The Journal of Legislative Studies, v. 7, n. 1, 2001.

MENEGUELO, R. El impacto de la democratización del Estado en el desarrollo de los partidos brasileños. In: CAVAROZZI, M. e MEDINA, J. A. (Orgs.). El asedio a la Política: los partidos latinoamericanos en la era neoliberal. Rosário: Konrad-Adenauer e Homo Sapiens Ediciones, 2003.

MILL, J. S. Considerações sobre o Governo Representativo. Brasília: UnB, 1981.

MIRANDA, G. L. O Comportamento dos Partidos na Câmara dos Deputados e no Senado Federal (1991-2007). Tese (Doutorado em Ciência Política) Universidade Federal de Minas Gerais, Belo Horizonte, 2008.

MONEY, J.; TSEBELIS, G. "Cicero's puzzle: Upper House power in comparative perspective". Internacional Political Science Review, n. 13,1992 , p. 25-43.

MONTESQUIEU. O Espírito das Leis. São Paulo: Abril Cultural, 1973.

NEIVA, P. Os Determinantes dos poderes das câmaras altas: federalismo ou presidencialismo? Dados, Rio de Janeiro, v. 49, 2006, p. 269-299.

PATTERSON, S. e MUGHAN, A. (Orgs.) Senates: Bicameralism in the Contemporary World. Ohio State University Press, 1999.

PEREIRA, C.; RENNO, L. O que é que o reeleito tem? Dinâmicas político-institucionais locais e nacionais nas eleições de 1998 para a Câmara dos Deputados. Dados, v. 44, n. 2, p. 133-172, 2001. 
PEREIRA, C.; MUELLER, B. Partidos fracos na arena eleitoral e partidos fortes na arena legislativa: a conexão eleitoral no Brasil. Dados, v. 46, n. 4, p. 735-771, 2003.

POWER, T. Optimism, Pessimism, and Coalitional Presidentialism: Debating the Institutional Design of Brazilian Democracy. Bulletin of Latin American Research, v. 29, n. 1, 2010, p. 18-33.

RAE, D. The Political Consequences of Electoral Laws. New Haven, Yale University Press, 1967.

RICCI, P. A produção legislativa de iniciativa parlamentar no Congresso: diferenças e similaridades entre a Câmara dos Deputados e o Senado Federal. In: LEMOS, L. B. (Org.). O Senado Federal no Pós-constituinte. Brasília: Senado Federal, Unilegis, 2008.

SANTOS, F. O Poder Legislativo no Presidencialismo de Coalizão. Ed. UFMG/luperj, 2003.

SARTORI, Giovanni. Teoria da democracia revisitada: o debate contemporâneo. São Paulo: Ática, 1994.

SCHMITT, C. Teologia Política: cuatro ensaios sobre la representación. Buenos Ayres: Struhart, 1998.

SHUGART, M. S.; CAREY, J. M. Presidents and Assemblies. Cambridge: Cambridge University Press, 1992.

SINCLAIR, B. Coequal Partner: the U.S. Senate. In: PATTERSON, S.; MUGHAN, A. (Orgs.) Senates: Bicameralism in the Contemporary World. Ohio State University Press, 1999.

STEPAN, A. Para uma nova análise comparativa do federalismo e da democracia: federações que restringem ou que ampliam o poder do demos. Dados, Rio de Janeiro, n. 42, 1999.

TAAGEPERA, R; SHUGART, M. Seats e Votes: the effects and determinants of electoral systems. New Haven: Yale University Press, 1989. 


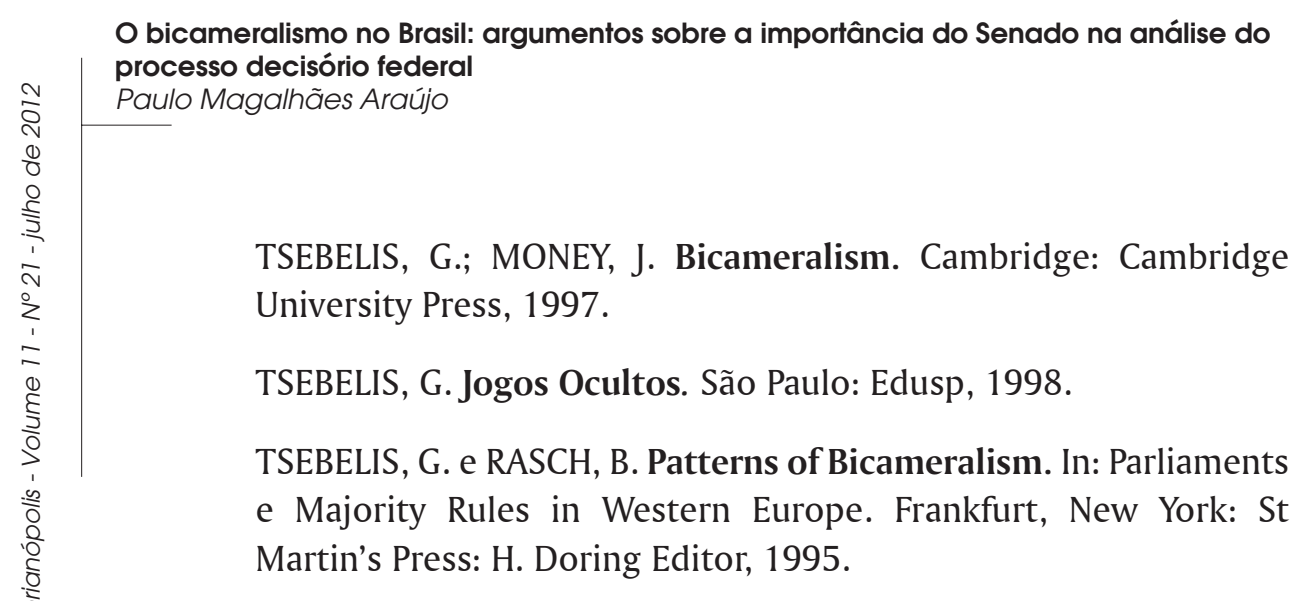

Sites consultados

CÂMARA DOS DEPUTADOS. Disponível em: < http://www.camara. gov.br>. Acesso em: 10 dez. 2011.

INTER-PARLIAMENTARY UNION. Disponível em: <ttp://www.ipu. br>. Acesso em: 10 dez. 2011.

INSTITUT FÜR IBEROAMERIKA-KUNDE. Disponível em: <http:// www.giga-hamburg.de >. Acesso em: 10 dez. 2011.

SENADO FEDERAL. Disponível em: < http://www.senado.gov.br > Acesso em: 10 dez. 2011.

\section{Abstract \\ The bicameral system in Brazil: the importance of the Senate in the federal decision-making process}

The paper analyzes the Brazilian bicameralism from the institutionalist perspective, in order to explore more complex than usual in the academic production, the power of the Senate in the decisions of the federal government. Unlike the most common approaches, which do not adequately consider the interdependent character of the functioning of the chambers of Congress, the analysis undertaken here explores the institutional mix between bicameralism and coalition presidentialism, to highlight the Senate, for their constitutional prerogatives, is a house highly influential in the decisions of the federal government. However, the analysis also points out that more or less impact of the House actions 
depends on its position in the decision-making and the consideration of contextual factors such as the structure of the coalition and other aspects of the decision situation.

Keywords: Potical institutions. Bicameralism. The Brazilian senate. Parliamentary behavior. 
